\title{
Solubilities of Sodium Nitrate, Sodium Nitrite, and Sodium Aluminate in Simulated Nuclear Waste
}

Date Manuscript Published: September 1984

\author{
D. A. Reynolds \\ D. L. Herting \\ Research and Engineering
}

Prepared for the U.S. Department of Energy

under Contract DE-AC06-77RL01030)

Rockwell Manford Operations

Energy Systems Group

P.O. Box 800

Plchland, Washington 99352 


\section{DISCLAIMER}

This report was prepared as an account of work sponsored by an agency of the United States Government. Neither the United States Government nor any agency Thereof, nor any of their employees, makes any warranty, express or implied, or assumes any legal liability or responsibility for the accuracy, completeness, or usefulness of any information, apparatus, product, or process disclosed, or represents that its use would not infringe privately owned rights. Reference herein to any specific commercial product, process, or service by trade name, trademark, manufacturer, or otherwise does not necessarily constitute or imply its endorsement, recommendation, or favoring by the United States Government or any agency thereof. The views and opinions of authors expressed herein do not necessarily state or reflect those of the United States Government or any agency thereof. 


\section{DISCLAIMER}

Portions of this document may be illegible in electronic image products. Images are produced from the best available original document. 


\section{DISTRIBUTION}

This report has been distributed according to the category "Nuclear Waste Management," UC-70, as given in the Standard Distribution for Unclassified Scientific and Technical Reports, T10-4500. 


\section{RHO-RE-ST-14 P}

\section{ABSTRACT}

Solubilities were determined for sodium nitrate, sodium nitrite, and sodium aluminate in synthetic nuclear waste liquor. Solubilities were determined as a function of temperature and solution composition (concentrations of sodium hydroxide, sodium nitrate, sodium nitrite, and sodium aluminate). Temperature had the greatest effect on the solubilities of sodium nitrate and sodium nitrite and a somewhat lesser effect on sodium aluminate solubility. Hydroxide had a great effect on the solubilities of all three salts. Other solution components had minor effects. 
Introduction ......................... 1

Background ........................... . . 1

Experimental Strategy ..................... . 3

Experimental Technique . . . . . . . . . . . . . . 6

Data Reduction ....................... 10

Sodium Nitrate....................... 10

Sodium Nitrite . . . . . . . . . . . . . . . 15

Sodium Aluminate . . . . . . . . . . . . . . . 19

Density .......................... . . 22

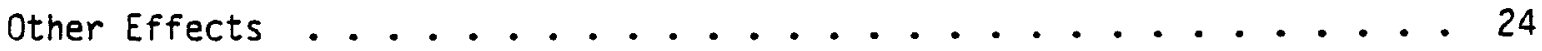

Implications of This Study . . . . . . . . . . . . . . 24

Acknowledgments ..................... . . 26

References...................... . . 26

Appendices:

A. Phase Diagram, Complete; Concentrations in Molalities . . . A-1

B. Phase Diagram, Complete; Concentrations in Molarities ... . B-1

FIGURES:

1. Experimental Design ................. 4

2. Apparatus Used to Measure Sodium Nitrate/Sodium Nitrite

Solubilities . . . . . . . . . . . . . . 7

3. Sodium Nitrate Versus Sodium Nitrite at $80^{\circ} \mathrm{C}$

and $1.2 \mathrm{~m}$ Sodium Aluminate ............. 11

4. Sodium Nitrate Versus Sodium Nitrite at $80^{\circ} \mathrm{C}$

and $0.6 \mathrm{M}$ Sodium Aluminate .............. 12

5. Sodium Nitrate Solubility ................ . 16

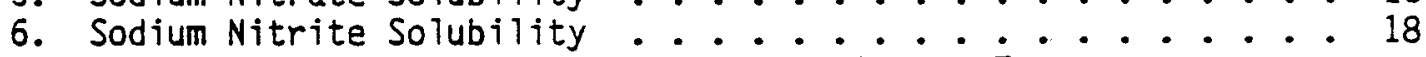

7. Sodium Aluminate Solubility as a Function of Temperature and Hydroxide Concentrations ............. 20

8. Sodium Aluminate Solubility ............ . . 23 
TABLES:

1. Composition of Typical Defense Waste . . . . . . . . . 3

2. Parameter Settings................ 5

3. Concentrations of Nonvariable Solution Components . . . . 6

4. Aluminate/Hydroxide Analyses of Sodium Aluminate Solubility. Experiments............... 9

5. Sodium Nitrate Solubility Equations ............ 14

6. Changes in Sodium Nitrate Solubility ........... 15

7. Sodium Nitrite Solubility Equations . . . . . . . . . 17

8. Changes in Sodium Nitrite Solubility . . . . . . . . . . 19

9. Sodium Aluminate Solubility Equations ............ 21

10. Changes in Sodium Aluminate Solubility .......... 22

11. Density Equations ................ 24 
RHO-RE-ST-14 P

\section{INTRODUCTION}

Hanford Defense Waste is a complex chemical system. The waste accumulated over a 40-yr period from nuclear fuel reprocessing for the defense program. While the waste contains large amounts of radioactive material, the bulk of the waste consists of nonradioactive chemicals that were used in the separation of the nuclear material.

The solubilities of three compounds (sodium nitrate, sodium nitrite, and sodium aluminate) in simulated waste were studied. These are the chemicals that have the largest effect on evaporator/crystallizer processing of the defense waste. Together with sodium hydroxide and water, they represent the principal components of Hanford waste solution. In the waste evaporator, sodium nitrate and sodium nitrita precipitate in the largest quantities, while sodium aluminate forms small crystals that rapidly increase the slurry viscosity.

The results of the solubility study are presented in this report. Since the objective was to simulate the solubilities of salts in the waste, the solutions contained not only the salts of interest but also other chemical species that are present in the waste. Therefore, this was not a typical phase equilibria study of salts in water.

\section{BACKGROUND}

Construction of the Hanford facility began in 1943 under the direction of the U.S. Army Corps of Engineers. Nucleal reactors were constructed to produce plutonium for the defense effort. Initially, 64 underground storage tanks were constructed to contain the high level radioactive waste from processing the reactor fuel. Eventually, 149 single-shell underground storage tanks were built with a capacity of about 94 million gallons. Since 1966, 20 double-she 11 underground storage tanks have been constructed. The double-shell design provides one more barriel to the environment than the original single-shell design. In the mid-1970s, commitment was made to deactivate the 149 single-she 11 tanks and store the high level liquid waste in double-she 11 tanks. The goal was met in November 1980.

Various evaporative techniques have been used since 1950 to reduce the volume of the liquid waste and to ultimately allow storage in the 20 doubleshell tanks. Initially, the waste was fairly dilute, and there were many tanks available for storage and processing. The evaporative process was fairly simple under those conditions. Currently, the waste is being made into a very concentrated slurry to minimize the storage volume.

The evaporator presently in use at the Hanford Site is a large $(25,000 \mathrm{ga} 1$ ) vacuum evaporator/crystallizer (Ref. 1). Forced recirculation increases the efficiency and slows the fouling of the reboiler. Typical feed rate is $100 \mathrm{gal} / \mathrm{min}$ with a minimum product slurry rate of $43 \mathrm{gal} / \mathrm{min}$. 
RHO-RE-ST-14 P

The slurry product is pumped through 2 -in. double-encased lines to the underground storage tanks. Some of the slurry lines are $1,700 \mathrm{ft}$ long. One of the major constraints in evaporating the waste is the need to pump the slurry through the long pipelines.

The pumpability of the slurry limits the evaporator product to a nominal 30 vol\% suspended solids. The solids are typically sodium nitrate, sodium nitrite, sodium carbonate, sodium aluninate, and trisodium phosphate. The slurry is allowed to settle in the tank, and the supernatant is often . returned to the evaporator for further concentration.

The sodium aluminate and trisodium phosphate are usually a small percentage of the solids, but are important solids as they build viscosity rapidly. The trisodium phosphate typically forms long needle-like crystals that make the slurry difficult to pump. The sodium aluminate forms in small "soda cracker" type crystals that make the siurry behave somewhat like a ge1. While not a problem in the evaporator/crystallizer, the sodium carbonate solids are usualiy less dense than the supernatant and form floating crusts in the storage tanks.

Current operating philosophy is to avoid making sodium aluminate in the early evaporator passes. On the final pass, as much water as possible is removed to make the minimum volume product. The slow crystallization kinetics of the aluminate are taken advantage of to keep the aluminate in solution until the product is in the storage tanks. There the aluminate will precipitate out and may produce an unpumpable product.

Operating experience showed that there were several misconceptions in our understanding of the process chemistry (Ref. 2). For example, temperature was found to affect the sodium nitrate and sodium nitrite solubilities much more than anticipated, and sodium aluminate precipitated from solutions in which it was thought to be unsaturated. While none of these events compromised the safe processing of the nuclear waste, they did point out the need for additional understanding of the process. That need formed the basis for the present study.

Because of the nature of the transformation reactions occurring in a nuclear reactor, essentially every element below atomic number 100 is in the reprocessing waste. Understanding the total phase equilibria is not practical. However, most elements are in small or trace quantities and can be disregarded. A typical analysis of the Hanford Defense Waste is shown in Table 1. As can be seen, sodium salts of nitrate, nitrite, and hydroxide are the major constituents in the waste. Sodium aluminate also is present in fairly high concentrations, and causes some special processing problems. Therefore, the major compounds of interest are sodium nitrate, sodium nitrite, sodium aluminate and sodium hydroxide. 
TABLE 1. Composition of

Typical Defense Waste.

\begin{tabular}{l|c}
\hline Component & Concentration \\
\hline $\mathrm{Al}(\mathrm{OH})_{4}$ & $1.01 \mathrm{M}$ \\
$\mathrm{OH}$ & $2.40 \mathrm{M}$ \\
$\mathrm{NO}_{3}$ & $3.63 \mathrm{M}$ \\
$\mathrm{NO}_{2}$ & $2.85 \mathrm{M}$ \\
$\mathrm{CO}_{3}$ & $0.58 \mathrm{M}$ \\
$\mathrm{Cl}$ & $0.27 \mathrm{M}$ \\
$\mathrm{PO}_{4}$ & $0.084 \mathrm{M}$ \\
$\mathrm{Na}$ & $10.7 \mathrm{M}$ \\
$\mathrm{TOC}^{*}$ & $0.58 \mathrm{~g} / \mathrm{L}$ \\
$137 \mathrm{Cs}$ & $0.597 \mathrm{Ci} / \mathrm{L}$ \\
$90 \mathrm{Sr}$ & $0.004 \mathrm{Ci} / \mathrm{L}$ \\
$\mathrm{H}_{2} \mathrm{O}$ & $54.5 \mathrm{Wt} \%$ \\
Density & $1.42 \mathrm{~g} / \mathrm{mL}$ \\
\hline
\end{tabular}

${ }^{\star}$ TOC = Tota 1 Organic Carbon.

\section{EXPERIMENTAL STRATEGY}

Because of the many components in the waste, determination of a complete phase diagram was not possible. Instead, just the three compounds of major importance were chosen. In addition, it was known that hydroxide concentration and temperature were important in the solubility of these compounds. There were, then, five variables in the experimental scheme: temperature, and the concentrations of sodiuln nitrate $\left(\mathrm{NaNO}_{3}\right)$, sodium nitrite $\left(\mathrm{NaNO}_{2}\right)$, sodium aluminate $\left(\mathrm{NaAlO}_{2}\right)$, and sodium hydroxide $(\mathrm{NaOH})$. (For lack of a precise empirical formula for sodium aluminate, $\mathrm{NaAlO}_{2}$ will be used through this report.)

As independent variables, the concentrations of $\mathrm{NaNO}_{3}, \mathrm{NaNO}_{2}$, and $\mathrm{NaAlO}_{2}$ were expected to have linear effects on solubility over the range of interest, so each was varied at two levels. Sodium hydroxide concentration and temperature were not expected to have linear effects, so each was varied over three levels.

Figure 1 shows how the experimental design was set up. At point 1 in the figure, $\mathrm{NaNO}_{3}$ solubility was measured at the high, but not saturated, levels of $\mathrm{NaNO}_{2}$ and $\mathrm{NaAlO}_{2}$. At point 2, $\mathrm{NaNO}_{3}$ solubility was measured at 
RHO-RE-ST-14P

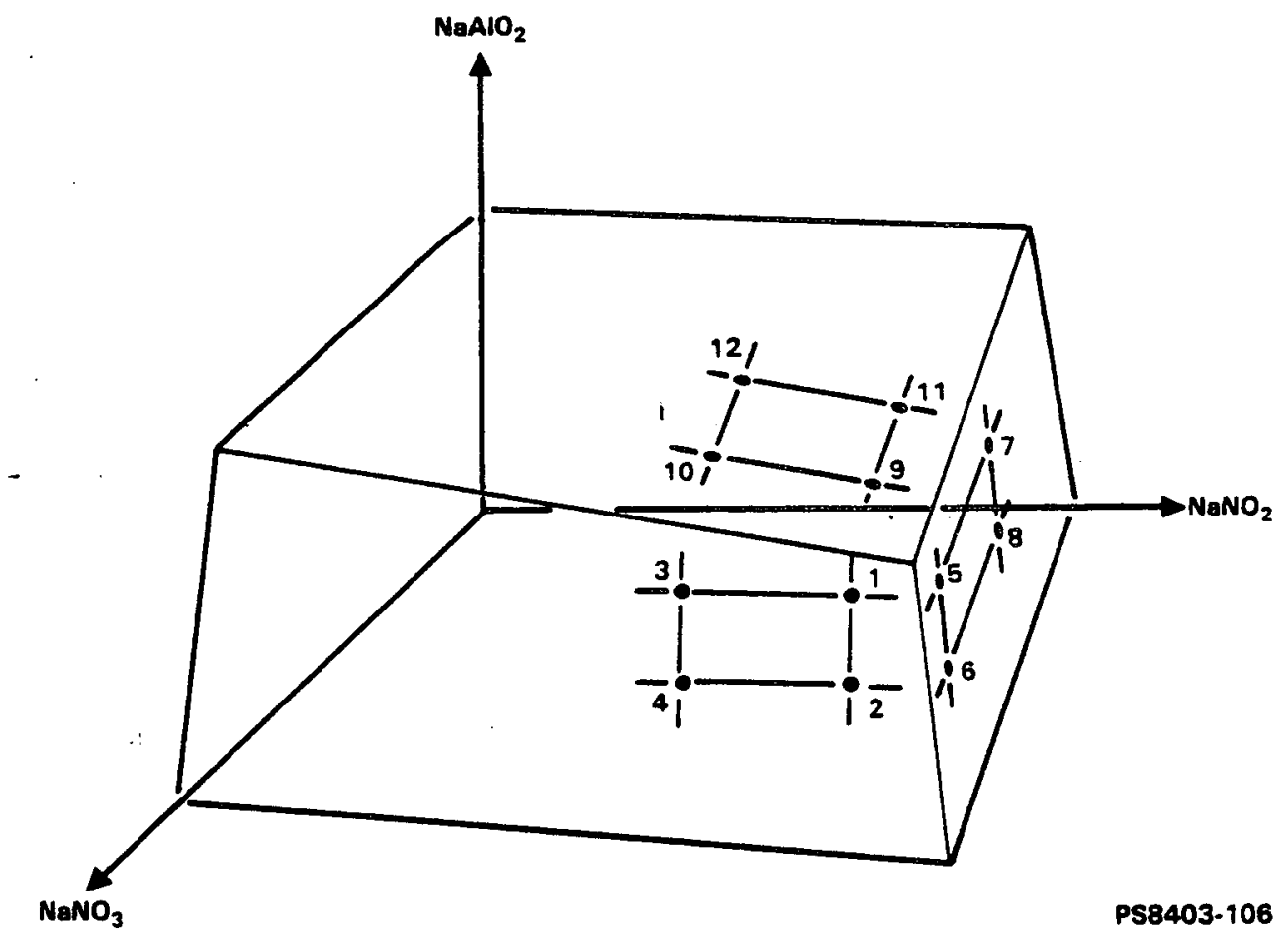

FIGURE 1. Experimental Design. 
the same high level of $\mathrm{NaNO}_{2}$ and a lower level of $\mathrm{NaAlO}_{2}$, and so on for points 3 and 4 . The surface containing the four points represents the solubility of $\mathrm{NaNO}_{3}$ as a function of $\mathrm{NaNO}_{2}$ and $\mathrm{NaAlO}_{2}$ concentrations at a given temperature and hydroxide concentration. Points 5-8 1ie in the righthand surface, which describes the $\mathrm{NaNO}_{2}$ solubility. The same high and low concentrations of $\mathrm{NaAlO}_{2}$ were used in. points $5-8$ as in points $1-4$. Points 9-12 lie in the top face, which describes the solubility of $\mathrm{NaAlO}_{2}$. Again, the high and low levels of $\mathrm{NaNO}_{2}$ and $\mathrm{NaNO}_{3}$ were consistent with the earlier points.

The parameter settings are summarized in Table 2. These twelve points constitute one "cell" of the experimental design. There are nine cells representing the nine possible temperature/hydroxide concentration combinations. The data in the appendices are arranged according to these cells, which are designated $A X, A Y . . . C Y, C Z$.

TABLE 2. Parameter Settings.

\begin{tabular}{c|c|r|r}
\hline $\begin{array}{c}\text { Point } \\
\text { number }\end{array}$ & $\mathrm{NaNO}_{3}$ & $\mathrm{NaNO}_{2}$ & $\mathrm{NaAlO}_{2}$ \\
\hline 1 & $\mathrm{OV} *$ & + & + \\
2 & $\mathrm{OV}$ & + & - \\
3 & $\mathrm{OV}$ & - & + \\
4 & $\mathrm{OV}$ & - & - \\
5 & + & $\mathrm{DV}$ & + \\
6 & + & $\mathrm{OV}$ & - \\
7 & - & $\mathrm{DV}$ & + \\
8 & - & $\mathrm{DV}$ & - \\
9 & + & + & $\mathrm{OV}$ \\
10 & + & - & $\mathrm{OV}$ \\
11 & - & + & $\mathrm{OV}$ \\
12 & - & - & $\mathrm{OV}$ \\
\hline
\end{tabular}

${ }^{\star}$ DV = Dependent Variable.

In the waste compositions of interest, inost salts are saturated or very close to saturation. Therefore, it was desirable to predict from the data the triple saturation point, or the point at which the three faces in Figure 1 converge. Hence, the high levels of the variables were to be held as close to saturation as was practical, while the low levels were chosen to be about half the high levels. This was complicated by the large changes in solubility with changes in temperature and hydroxide concentration. For example, 8 molal sodium nitrite may be close to saturation at high hydroxide 
concentration but would be far below saturation at low hydroxide concentration. Therefore, the high and low levels for the variables were not held constant from one cell to another, but they were held constant within each cell.

In addition to the chemcial species of interest, other chemicals were present in the solutions. These chemicals were kept constant at one level throughout the experimental program. They represented the additional chemicals that are present in the waste but that were not studied in this experimental phase. These chemicals, shown in Table 3, were set below the ir saturation points so that they were not precipitate. However, their presence formed a background matrix similar to that found in the actual wastes.

TABLE 3. Concentrations of Nonvariable Solution

Components.

\begin{tabular}{l|r}
\hline Component & Molality \\
\hline EOTAa & 0.051 \\
Citrateb & 0.083 \\
$\mathrm{Na}_{3} \mathrm{PO}_{4}$ & 0.070 \\
$\mathrm{Na}_{2} \mathrm{CO}_{3}$ & 0.070 \\
$\mathrm{Na}_{2} \mathrm{SO}_{4}$ & 0.016 \\
\hline \multicolumn{2}{|c|}{ aEDTA = tetrasodium salt of } \\
ethylenediaminetetraacetic acid. \\
$\therefore$ bTrisodium citrate.
\end{tabular}

EXPERIMENTAL TECHNIQUE

The solubilities of sodium nitrate and sodium nitrite were determined using the apparatus in Figure 2. The vessel was jacketed for precise temperature control, which was provided by a Lauda/Brinkmann constant temperature circulator. The baffles in the vessel greatly aided the stirring efficiency of the Teflon-coated magnetic stir bar.

To illustrate the procedure for measuring solubility, the determination of sodium nitrate solubility in run $A X-1$ will be described. Exactly $100.00 \mathrm{~g}$ of the appropriate stock solution was introduced into the test apparatus. The stock solution contained $2.03 \mathrm{~m} \mathrm{NaAlO} 2,9.22 \mathrm{~m} \mathrm{NaOH}$, $0.014 \mathrm{~m} \mathrm{Na}_{2} \mathrm{SO}_{4}$, and $0.07 \mathrm{~m} \mathrm{Na} \mathrm{CO}_{3}$. ( $\mathrm{m}=$ molality, moles solute per kilogram water.) The density was $1.386 \mathrm{~g} / \mathrm{mL}$ and the percent water was 61.80 . 


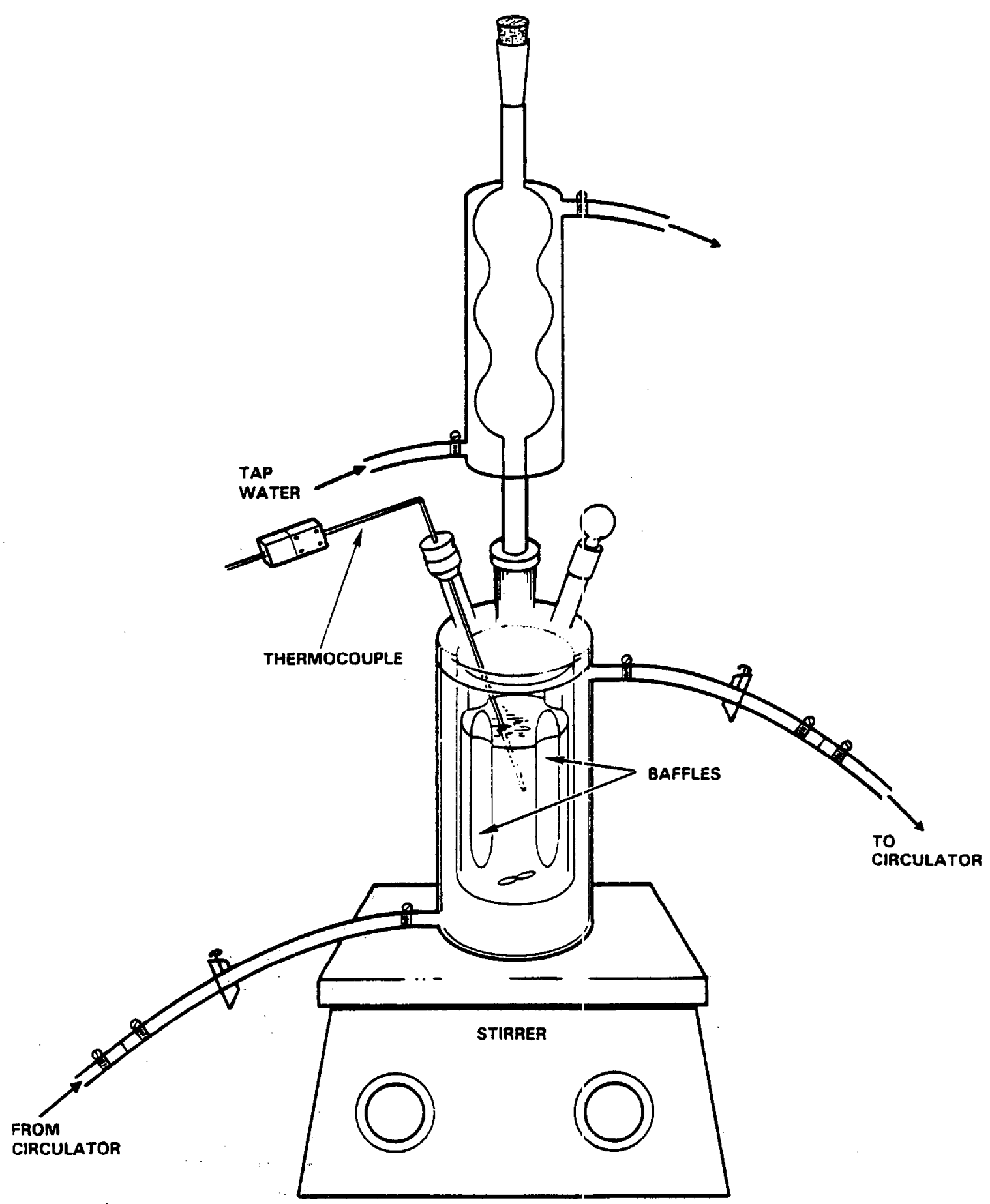

PS8403-107

FIGURE 2. Apparatus Used to Measure Sodium Nitrate/Sodium Nitrite Solubilities. 
To the stock solution were added $0.98 \mathrm{~g} \mathrm{H}_{4}$ EDTA (anhydrous ethylenediaminetetraacetic acid), $1.63 \mathrm{~g} \mathrm{Na} 3 \mathrm{C}_{6} \mathrm{H}_{5} \mathrm{O}_{7} \cdot 2 \mathrm{H}_{2} \mathrm{O}$ (trisodium citrate dihydrate), $1.52 \mathrm{~g} \mathrm{Na}_{3} \mathrm{PO}_{4} \cdot 12 \mathrm{H}_{2} \mathrm{O}$ (trisodium phosphate), $29.41 \mathrm{~g} \mathrm{NaNO}_{3}$, and $32.10 \mathrm{~g} \mathrm{NaNO} 2$. The solution was heated at $80^{\circ} \mathrm{C}$ until all the solids dissolved, cooled to nucleation $\left(52.5^{\circ} \mathrm{C}\right)$, then heated slowly. When the solution began to clear again, one drop was placed on a slide and examined under a microscope to verify that the crystals that were dissolving were, in fact, $\mathrm{NaNO}_{3}$ crystals. As the last of the crystals dissolved, the dissolving temperature was recorded $\left(57.1^{\circ} \mathrm{C}\right)$, and then $1.0 \mathrm{~g} \mathrm{NaNO}_{3}$ was added. The cycle (heat, dissolve, cool to nucleation, heat slowly to dissolving temperature, add $\mathrm{NaNO}_{3}$ ) was repeated until the dissolving temperature reached $62.0^{\circ} \mathrm{C}$. A plot was constructed of dissolving temperature vs. weight of $\mathrm{NaNO}_{3}$ added, and the saturation point of $\mathrm{NaNO}_{3}$ at $60^{\circ} \mathrm{C}$ was determined by interpolation. Nucleation temperatures, which were typically about $5^{\circ} \mathrm{C}$ below the dissolving temperatures, were also plotted as a double-check on the identity of the solid phase. Any change in solid phase during the course of the experiment showed up as a discontinuity in the nucleation temperature plot.

Sodium aluminate solubility could not be determined by the same method because of the very slow crystallization rate. Run AX-9 is typical of the procedure used for measuring sodium aluminate solubility. Beginning with $80 \mathrm{~g} \mathrm{H}_{2} \mathrm{O}$ in a beaker, the following chemicals were added: $83.26 \mathrm{~g} \mathrm{NaAlO}_{2}$ (technical grade), $36.20 \mathrm{~g} \mathrm{NaOH}, 46.85 \mathrm{~g} \mathrm{NaNO}_{3}, 50.78 \mathrm{~g} \mathrm{NaNO}_{2}, 1.46 \mathrm{~g}$ $\mathrm{H}_{4}$ EDTA, $2.41 \mathrm{~g} \mathrm{Na} 3 \mathrm{C}_{6} \mathrm{H}_{5} \mathrm{O}_{7} \cdot 2 \mathrm{H}_{2} \mathrm{O}, 0.20 \mathrm{~g} \mathrm{Na}_{2} \mathrm{SO}_{4}$, and $0.74 \mathrm{~g} \mathrm{Na} 2 \mathrm{CO}_{3}$. The temperature of the solution was maintained at $90^{\circ}-110^{\circ} \mathrm{C}$ during the dissolution. After all the chemicals had dissolved, the total solution weight was adjusted to $315.60 \mathrm{~g}$ by adding water. A sample was taken for anaiysis (described below), and the remaining solution was transferred to a screw cap Teflon $250-\mathrm{mL}$ flask and placed in a $60^{\circ} \mathrm{C}$ water bath shaker. (For the $100^{\circ} \mathrm{C}$ runs, samples were stored in a gravity convection oven.) Once each week for the following 4 weeks, an aliquot of the solution was taken for analysis.

Analyses were performed in the following way. A vacuum filtration apparatus was set up inside a large forced-air oven in which the temperature was maintained at $5^{\circ} \mathrm{C}$ above the temperature of the solution (slurry) to be filtered. A 10- to $15-\mathrm{mL}$ sample of the solution was placed in a large $(350 \mathrm{~mL})$ glass frit Buchner filter funnel and vacuum filtered into a small receiver. Because of the large filter surface area, filtration was very rapid, taking only 5-30 seconds. Pycnometer flasks (2 mL) were used to measure the filtrate density without dilution. For chemical analysis, the filtrate was diluted using an automatic Oxford Macro-Set pipette. The dilution was analyzed for $\mathrm{NaAlO}_{2}$ and $\mathrm{NaOH}$ molarities, usually within $24 \mathrm{~h}$.

Table 4 contains sample data of the solution analyses as a function of time. Note how the aluminate concentration decreases with time, until it reaches its equilibrium saturation point. The hydroxide concentration, meanwhile, tends to increase with time. This increase is due to the fact that the solution volume decreases as the sodium aluminate precipitates, while the number of moles of hydroxide in the solution remains constant. Concentrations of both aluminate and hydroxide remain constant once equilibrium is reached. 
TABLE 4. Aluminate/Hydroxide Analyses of Sodium Aluminate Solubility Experiments.

\begin{tabular}{l|c|c|c|c|c|c|c|c|c|c}
\hline & \multicolumn{4}{|c|}{ Aluminate molarity } & \multicolumn{5}{c}{ Hydroxide molarity } \\
\cline { 2 - 11 } Samp 1e & \multicolumn{4}{|c|}{ Time in weeks } & \multicolumn{5}{c|}{ Time in weeks } \\
\cline { 2 - 11 } & 0 & 1 & 2 & 3 & 4 & 0 & 1 & 2 & 3 & 4 \\
\hline BY-9B & 3.53 & 2.93 & 1.92 & 1.99 & 1.90 & 2.68 & 2.68 & 2.62 & 2.93 & 2.78 \\
BY-10B & 3.65 & 3.29 & 2.16 & 2.18 & 2.16 & 2.80 & 2.85 & 2.86 & 2.98 & 2.96 \\
BY-11B & 3.72 & 3.01 & 2.13 & 2.15 & 2.10 & 2.84 & 2.96 & 2.87 & 2.98 & 2.96 \\
BY-12B & 3.90 & 2.70 & 2.46 & 2.20 & 2.42 & 3.01 & 3.14 & 3.10 & 3.19 & 3.17 \\
\hline
\end{tabular}

Before going on to a presentation of the results, a word should be said about the accuracy of the data. Reproducibility (precision) for the nitrate/ nitrite solubility measurements was generally better than one percent. The accuracy depends on how well the molalities can be calculated. The moles of chemicals added is well known. Except for sodium aluminate, reagent grade chemicals were used throughout, and no attempt at further purification was made. Since it is not possible to purchase reagent grade sodium aluminate, stock solutions were prepared containing $\mathrm{NaAlO}_{2}$ and $\mathrm{NaOH}$. The solutions were analyzed to verify the aluminate and hydroxide concentrations. The amount of water in the solutions, which is probably the most uncertain factor in the molality calculations, was based solely on the aluminate/hydroxide analyses and solution density. Adjustments had to be made in the calculations for the amount of water to account (a) for the water of hydration in the phosphate and citrate salts, and (b) for the water produced by the neutralization reaction when EDTA was added in the acid form. The possible errors in the molality calculations are estimated to be about $2 \%$ to $3 \%$.

The concentration unit used throughout the experiments was molality. Molality was preferred over molarity because the solution volume changes with changes in temperature and additions of solute, while the amount of water remains constant. Densities were determined for all solutions so that a conversion from molality to molarity could be performed. The conversion was desirable for three reasons. The first was that the plant operations use molarity. The second was to allow comparison of the results of this study with previous studies. The third was to provide a check on the accuracy of the molalities by comparison to the actual solution analyses performed by the Analytical Laboratory, which reports all data in molarity.

By comparing the calculated molarities to molarities determined by actual analysis, the true accuracy of the experiments can be estimated. Eleven standard solutions of known nitrate and nitrite concentrations were submitted to the Analytical Laboratory along with eight solutions from the solubility experiments. For the standard solutions, the analytical results average $98 \%( \pm 5 \%)$ of the true value for the nitrate and $96 \%( \pm 3 \%)$ for the 
nitrate. For the other eight solutions, the analytical results averaged $95 \%$ $(+3 \%)$ of the calculated values for both nitrate and nitrite. The same eight solutions were analyzed in the process development laboratory for aluminate and hydroxide, and the results averaged $97 \%( \pm 3 \%)$ of the calculated molarities. These values are within the accuracy of the measurements used for the conversion. In summary, the calculated molarities are accurate to within $\pm 3 \%$ and may be biased $1 \%-2 \%$ high.

\section{DATA REDUCTION}

There were, in a 11, 263 experimental runs. The resulting data represent the regions of saturation for three species. Both molalities and molarities were calculated from the data. The concentrations of a 11 the runs are presented in the appendices.

Representing the data is not easy. The common methods such as reciprocal salts diagrams are not applicable to the system that was studied. Five variables must be represented in, at best, three-dimensional plots. Clearly, not all of the variables can be displayed at once. Plots of various slices of the five-dimensional space can clarify some of the observations.

The data were regressed to give several equations for use in interpolation and prediction. For each chemical compound there are four equations given, two equations each for molality and molarity. The first equation in each pair has many terms, and includes all effects that were found to be statistically valid. The shorter equation of each pair is limited to a maximum of four terms, and is designed to give almost the same precision as the long equation with less effort for entering into a hand calculator. Accompanying the equations are the appropriate regression coefficient $\left(R^{2}\right)$ values. The $R^{2}$ value is a measure of how well the equation fits the data. An $R^{2}$ value of 1.0 represents a perfect fit. A smal1 number indicates a poorer fit. A poor fit may be caused by several things. The data may have a large scatter, or some important term may not have been included in the regression. Also accompanying the equations is a number called the Standard Error. This is similar to the standard deviation and is useful in estimating the error-band associated with the equation.

\section{SODIUM NITRATE}

Figures 3 and 4 show the solubility of sodium nitrate plotted against the concentration of sodium nitrite at one temperature and one sodium aluminate concentration. The sodium hydroxide concentrations are represented by the three sets of lines. The horizontal lines indicate sodium nitrate solubility. The area below each line represents an unsaturated solution. Saturated solution are represented by the lines. 
RHO-RE-ST-14 P

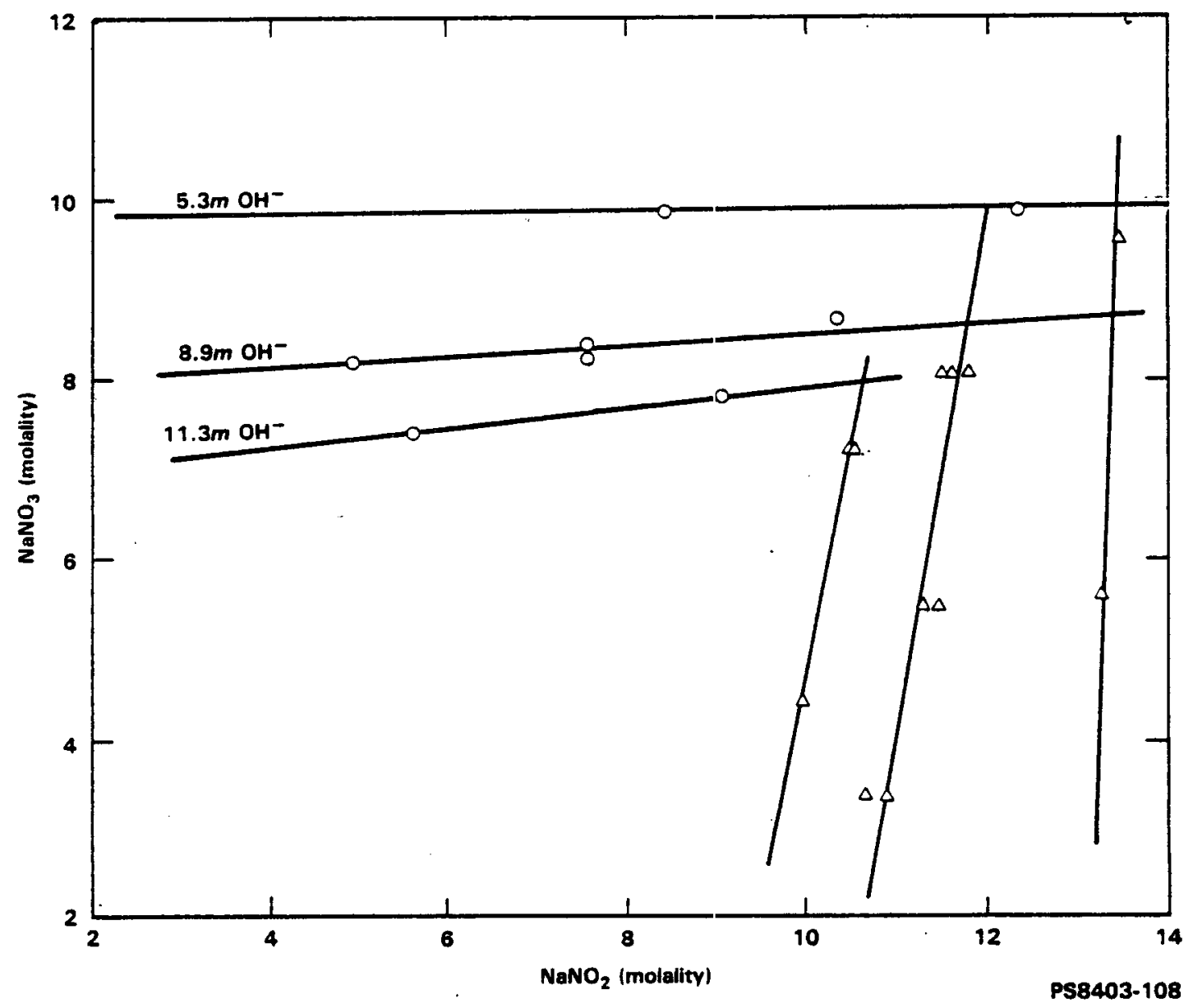

- EIGURE 3. Sodium Nitrate Versus Sodiurn Nitrite at $80^{\circ} \mathrm{C}$ and $1.2 \mathrm{~m}$ Sodium Aluminate. 
RHO-RE-ST-14 P

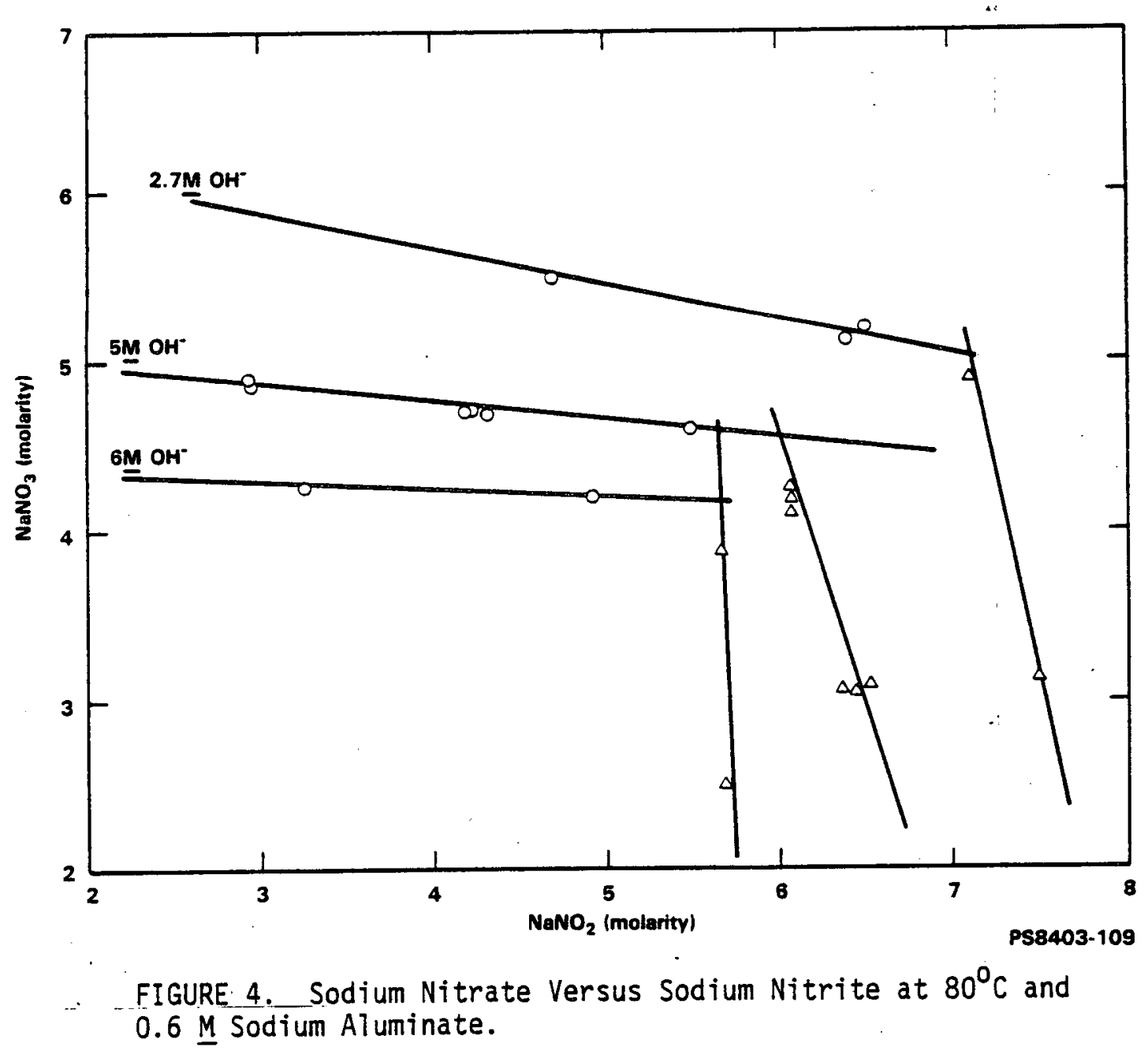


A mixture of solid sodium nitrate and saturated solution is above each line. The vertical lines represent the solubility of sodium nitrite. The area to the left of each line represents unsaturated solution. The area to the right represents solid sodium nitrite in equilibrium with saturated solution.

In Figure 3 the various lines clearly show that sodium hydroxide concentration has a large influence on sodium nitrate solubility. The $\mathrm{NaNO}_{3}$ lines slope upward slightly, which shows that sodium nitrite concentration has an influence on $\mathrm{NaNO}_{3}$ solubility. However, since the lines are fairly flat, $\mathrm{NaNO}_{2}$ concentration has a much smaller influence than $\mathrm{NaOH}$ concentration. Notice that the slopes change slightly in going from one line to another. This demonstrates the existence of a nitrite-hydroxide interaction. Temperature and sodium aluminate concentration are constant for this figure, so their effects are not shown.

In Figure 4 , which shows the same data in molarity units, the most striking difference is the change of slope of the constant-hydroxide lines. In molality units, increasing the nitrite concentration increases the solubility of the nitrate. In molarity units, nitrate solubility is suppressed with increasing nitrite. This effect is caused by the increase in solution volume as sodium nitrite is added. Imagine one liter of solution low in nitrite and saturated in nitrate. Now add a couple hundred grams of sodium nitrite and enough sodium nitrate to resaturate the solution. The new solution will have a higher nitrate molality (more $\mathrm{NaNO}_{3}$ but the same amount of water) and a lower nitrate molarity (volume increase outweighs salt increase). The effects of the other variables are approximately the same in molality and molarity units.

Equations for sodium nitrate solubility are shown in Table 5 . The first equation is for molality units with all statistically significant factors included. The equation contains factors for hydroxide, nitrite and aluminate concentrations, and temperature. The squared terms for temperature and hydroxide concentration mean that sodium nitrate solubility is not linear with these variables. Also included are several interaction terms. The molarity equation has about the same terms, but some of the interaction terms are not present. The $R^{2}$ values are very near 1.0 , which means that the equations represent the data very closely. The equations should be used only for the regions covered by the experimental points, as shown in the table.

Because of the many interactions, variables appear in several terms in the equations. Therefore, it is not readily apparent what effect any given variable has. The equations may be used to determine what a small change (say $1 \%$ ) in one variable causes in sodium nitrate solubility. The results of such changes are shown in Table 6 . This table needs some explanation. The "percentage change in $\mathrm{NaNO}_{3}$ " is the average change in sodium nitrate solubility with a $1 \%$ change in one of the variables. Notice that the temperature effect is larger in molality units than in molarity units, because the volume of the solution increases with temperature. The change in the nitrite effect from enhancing $\mathrm{NaNO}_{3}$ solubility in molality units $(+0.07)$ to the reverse effect in molarity units $(-0.3)$ is explained above. 
TABLE 5. Sodium Nitrate Solubility Equations.

Molality Units

Full equation:

$$
\begin{aligned}
& {\left[\mathrm{NaNO}_{3}\right]=9.192-0.0458(\mathrm{TEMP})-0.647[\mathrm{OH}]-0.205\left[\mathrm{NO}_{2}\right]-0.487\left[\mathrm{ATO}_{2}\right]} \\
& +0.00124(\text { TEMP })^{2}+0.0214[\mathrm{OH}]^{2}+0.00229(\text { TEMP) }[\mathrm{OH}] \\
& +0.00176\left(\text { TEMP) }\left[\mathrm{NO}_{2}\right]+0.00580(\mathrm{TEMP})[\mathrm{A} \mathrm{10} 2]+0.0175[\mathrm{OH}]\left[\mathrm{NO}_{2}\right]\right. \\
& R^{2}=0.9991 \quad \text { Std. Error }=0.0908
\end{aligned}
$$

Simplified equation:

$$
\begin{gathered}
{\left[\mathrm{NaNO}_{3}\right]=4.940-0.333[\mathrm{OH}]+0.000918(\mathrm{TEMP})\left[\mathrm{NO}_{2}\right]+0.000950(\mathrm{TEMP})^{2}} \\
\mathrm{R}^{2}=0.9965 \quad \text { Std. Error }=0.1711
\end{gathered}
$$

Val id Ranges:

TEMP from $60^{\circ}$ to $100^{\circ} \mathrm{C}$

$\mathrm{OH}$ from $5.0 \mathrm{~m}$ to $11.5 \mathrm{~m}$

$\mathrm{NO}_{2}$ from $3.5 \mathrm{~m}$ to $14.5 \mathrm{~m}$

$\mathrm{A} \mathrm{O}_{2}$ from $1.0 \mathrm{~m}$ to $3.0 \mathrm{~m}$

\section{Molarity Units}

Full equation:

$$
\begin{gathered}
{\left[\mathrm{NaNO}_{3}\right]=5.537+0.0224(\mathrm{TEMP})-0.627[\mathrm{OH}]-0.270\left[\mathrm{NO}_{2}\right]-0.747\left[\mathrm{ATO}_{2}\right]} \\
+0.000208(\mathrm{TEMP})^{2}+0.016[\mathrm{OH}]^{2}+0.0146[\mathrm{OH}]\left[\mathrm{NO}_{2}\right]+0.058[\mathrm{OH}]\left[\mathrm{AlO} \mathrm{O}_{2}\right] \\
\mathrm{R}^{2}=0.9960 \quad \text { Std. Error }=0.0697
\end{gathered}
$$

Simplified equation:

$$
\begin{gathered}
{\left[\mathrm{NaNO}_{3}\right]=5.552-0.205\left[\mathrm{NO}_{2}\right]-0.499\left[\mathrm{ATO}_{2}\right]-0.362[\mathrm{OH}]+0.000347(\mathrm{TEMP})^{2}} \\
R^{2}=0.9949 \quad \text { Std. Error }=0.0767
\end{gathered}
$$

Valid Ranges:

TEMP from $60^{\circ}$ to $100^{\circ} \mathrm{C}$

$\mathrm{OH}$ from $2 . \mathrm{OM}$ to $7.5 \mathrm{M}$

$\mathrm{NO}_{2}$ from 2.0 M to $7 . \overline{\mathrm{OM}}$

$\mathrm{AlO}_{2}$ from $0 . \overline{\mathrm{M}}$ to $1 . \overline{\mathrm{M}}$ 
TABLE 6. Changes in Sodium Nitrate Solubility.

\begin{tabular}{l|c|c}
\hline \multirow{2}{*}{$\begin{array}{c}\text { Change in } \\
\text { variabie (1\%) }\end{array}$} & \multicolumn{2}{|c}{$\begin{array}{c}\text { Percentage } \\
\text { change in NaNO } 3\end{array}$} \\
\cline { 2 - 3 } & Molality & Molarity \\
\hline Temperature & 1.5 & 1.0 \\
Hydroxide & -0.3 & -0.3 \\
Nitrite & 0.07 & -0.3 \\
Aluminate & -0.003 & -0.2 \\
\hline
\end{tabular}

Figure 5 is a graphical representation of the molarity equation for $\mathrm{NaNO}_{3}$ solubility. The temperature and hydroxide effects can be seen clearly. The solid lines represent the saturation concentration of sodium nitrate when sodium nitrite and sodium aluminate are both saturated. The dotted lines represent solutions with $\mathrm{NaNO}_{3}$ saturated and with $\mathrm{NaNO}_{2}$ and $\mathrm{NaAlO}_{2}$ at half saturation.

\section{SODIUM NITRITE}

Sodium nitrite is much more soluble than was supposed. Figures 3 and 4 show the $\mathrm{NaNO}_{2}$ solubility as a function of sodium hydroxide and sodium nitrate concentrations. Most of the trends puresented for sodium nitrate solubility hold for sodium nitrite, as well. For example the positive slopes of the $\mathrm{NaNO}_{2}$ solubility lines in Figure 3 show that increasing $\mathrm{NaNO}_{3}$ concentration increases the $\mathrm{NaNO}_{2}$ solubility, as measured in molality units, while the reverse is true for molarity (Fig. 4). The distances between lines show the strong influence of $\mathrm{NaOH}$ concentration in both figures.

The equations for sodium nitrite solubility are shown in Table 7 . The molality equations display nonlinear terms for hydroxide concentration and temperature. Nitrate and aluminate concentrations both appear in linear terms. There are several terms to describe the various interactions. The molarity equation is simple enough that only one equation is given. The relative effects of the variables can be seen in Table 8 .

Figure 6 represents the molarity equation for sodium nitrite solubility. It is similar to the one for sodium nitrate (Fig. 5). The dotted lines represent half-saturated solutions, and the solid lines represent solutions saturated in sodium nitrate and sodium aluminate. The effects of temperature and hydroxide concentration are clearly evident. 


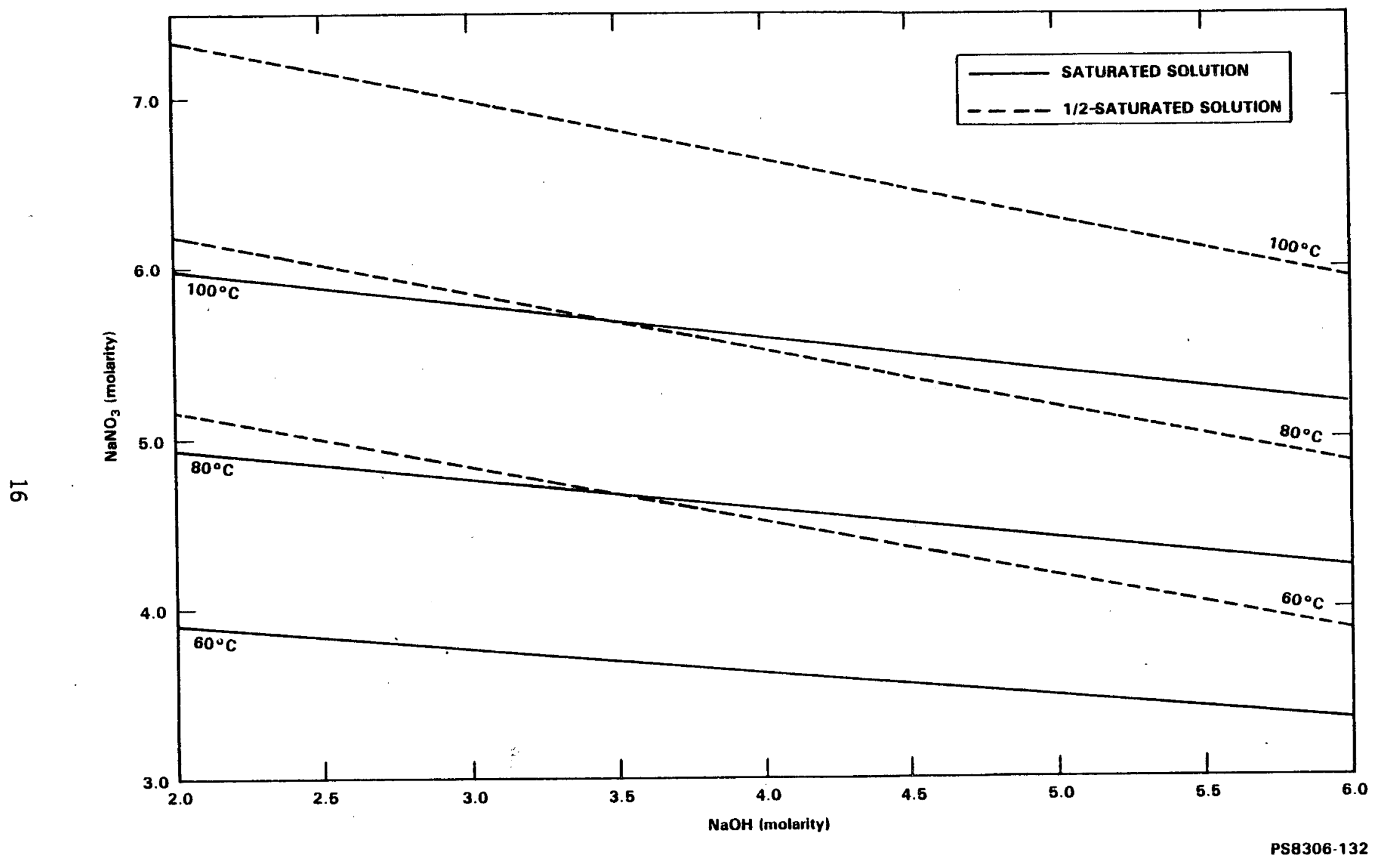

FIGURE 5. Sodium Nitrate Solubility. 
RHO-RE-ST-14 P

TABLE 7. Sodium Nitrite Solubility Equations.

Molality Units

Fu11 equation:

$$
\begin{gathered}
{\left[\mathrm{NaNO}_{2}\right]=14.321-0.104(\mathrm{TEMP})-0.931[\mathrm{OH}]-0.268\left[\mathrm{NO}_{3}\right]-0.514\left[\mathrm{AlO}_{2}\right]} \\
+0.00175(\mathrm{TEMP})^{2}+0.0216[\mathrm{OH}]^{2}+0.00321(\mathrm{TEMP})\left[\mathrm{NO}_{3}\right] \\
+0.00567(\mathrm{TEMP})\left[\mathrm{AlO}_{2}\right]+0.0140[\mathrm{OH}]\left[\mathrm{NO}_{3}\right] \\
\mathrm{R}^{2}=0.9989 \quad \text { Std. Error }=0.1307
\end{gathered}
$$

Simplified equation:

$$
\begin{gathered}
{\left[\mathrm{NaNO}_{2}\right]=7.315-0.489[\mathrm{OH}]+0.00133(\mathrm{TEMP})\left[\mathrm{NO}_{3}\right]+0.00123(\mathrm{TEMP})^{2}} \\
\mathrm{R}^{2}=0.9982 \quad \text { Std. Error }=0.228
\end{gathered}
$$

Valid Ranges:

TEMP from $60^{\circ}$ to $100^{\circ} \mathrm{C}$

$\mathrm{OH}$ from $5.0 \mathrm{~m}$ to $11.5 \mathrm{~m}$

$\mathrm{NO}_{3}$ from $3.0 \mathrm{~m}$ to $12.0 \mathrm{~m}$

$\mathrm{AlO}_{2}$ from $1.0 \mathrm{~m}$ to $3.0 \mathrm{~m}$

\section{Molarity Units}

Futr equation:

$$
\begin{gathered}
{\left[\mathrm{NaNO}_{2}\right]=7.549-0.495[\mathrm{OH}]-0.336\left[\mathrm{NO}_{3}\right]-0.642\left[\mathrm{~A} 10_{2}\right]+0.000424(\mathrm{TEMP})^{2}} \\
\mathrm{R}^{2}=0.9908 \quad \text { Std. Error }=0.1334
\end{gathered}
$$

Valid Ranges:

TEMP from $60^{\circ}$ to $100^{\circ} \mathrm{C}$

$\mathrm{OH}$ from $2 . \mathrm{OM}$ to $7.5 \mathrm{M}$

$\mathrm{NO}_{2}$ from 2.0 0 to $5 . \overline{\mathrm{M}}$

$\mathrm{A}_{2} \mathrm{O}_{2}$ from $0 . \overline{5} \mathrm{M}$ to $1 . \overline{6} \mathrm{M}$ 


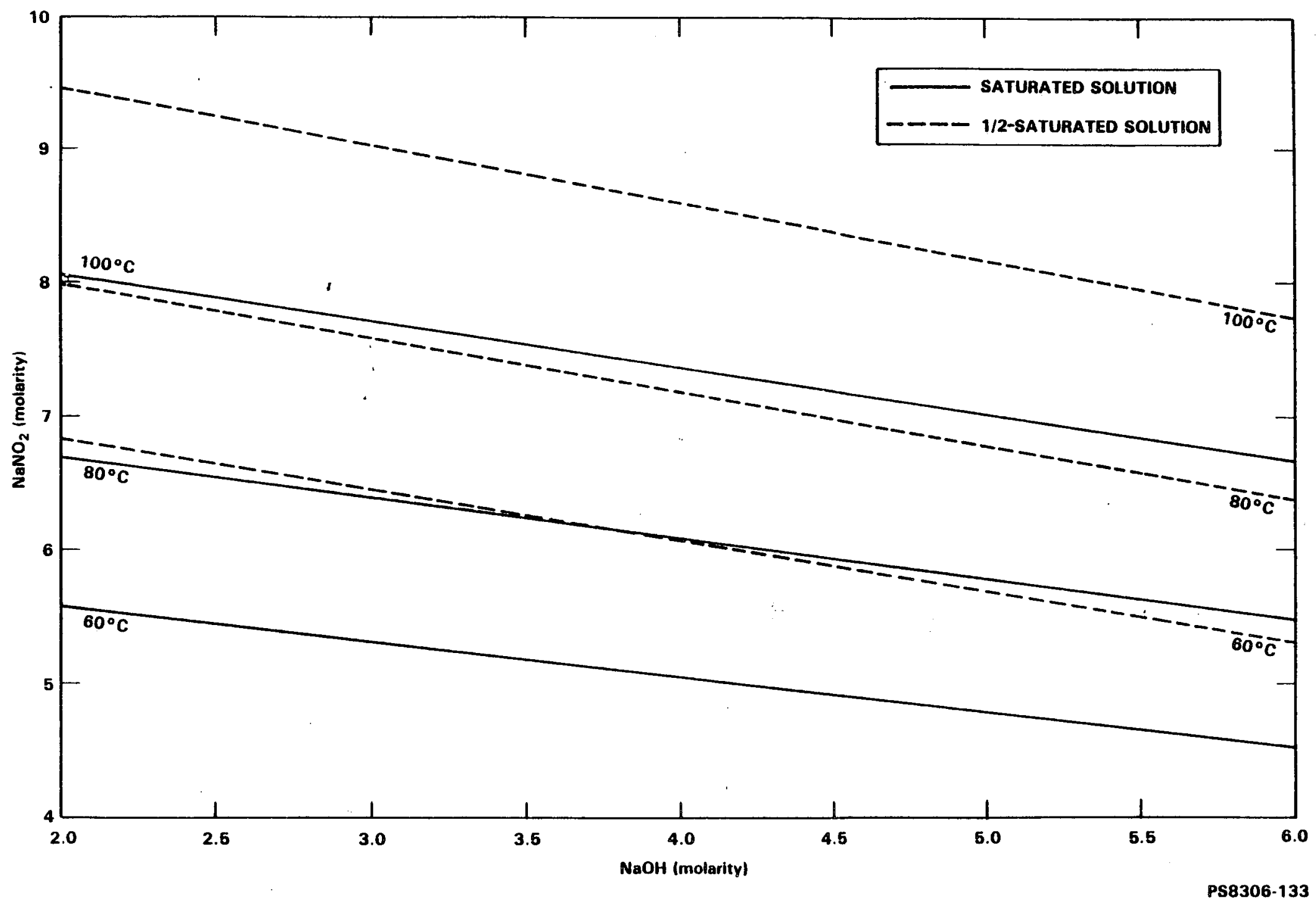

FIGURE 6. Sodium Nitrite Solubility. 
TABLE 8. Changes in Sodium Nitrite Solubility.

\begin{tabular}{l|c|c}
\hline \multirow{2}{*}{$\begin{array}{c}\text { Change in } \\
\text { variable (1\%) }\end{array}$} & \multicolumn{2}{|c}{$\begin{array}{c}\text { Percentage } \\
\text { changle in NaNO } 3\end{array}$} \\
\cline { 2 - 3 } & Molality & Molarity \\
\hline Temperature & 1.4 & 1.0 \\
Hydroxide & -0.3 & -0.3 \\
Nitrite & 0.07 & -0.3 \\
Aluminate & -0.02 & -0.1 \\
\hline
\end{tabular}

\section{SODIUM ALUMINATE}

Sodium aluminate solubility behavior is slightly different from that observed for sodium nitrate and sodium nitrite. While temperature and hydroxide concentration still have the largest effects on the shape of the solubility surface, the total amount of $\mathrm{NaA}_{1} \mathrm{l}_{2}$ dissolved is much lower than the amounts of $\mathrm{NaNO}_{3}$ and $\mathrm{NaNO}_{2}$. Figure 7 shows the solubility of sodium aluminate as a function of temperature and hydroxide concentrations. In general, the solubility increases with temperature and with decreasing $\mathrm{NaOH}$ concentration. However, there is a region at low $\mathrm{NaOH}$ concentration where increasing the temperature decreases the solubility. The figure does not show the nitrate/nitrite effects. There is a fairly strong interaction between nitrate and nitrite which may be due to a total ionic strength effect.

The regression equations for sodium aluminate solubility are shown in Table 9. These equations have larger standard errors than the corresponding equations for $\mathrm{NaNO}_{3}$ and $\mathrm{NaNO}_{2}$ because of a larger scatter in the data. Therefore, the equations can be used to predict $\mathrm{NaAlO}_{2}$ solubility to within an uncertainty of about $10 \%$.

The sensitivity analysis results are shown in Table 10. In molality units, the outcome is similar to the behavior of $\mathrm{NaNO}_{3}$ and $\mathrm{NaNO}_{2}$, except that $\mathrm{NaOH}$ concentration has a stronger effect in this case. In molarity units, $\mathrm{NaOH}$ concentration is the dominant effect. 
RHO-RE-ST -14 P

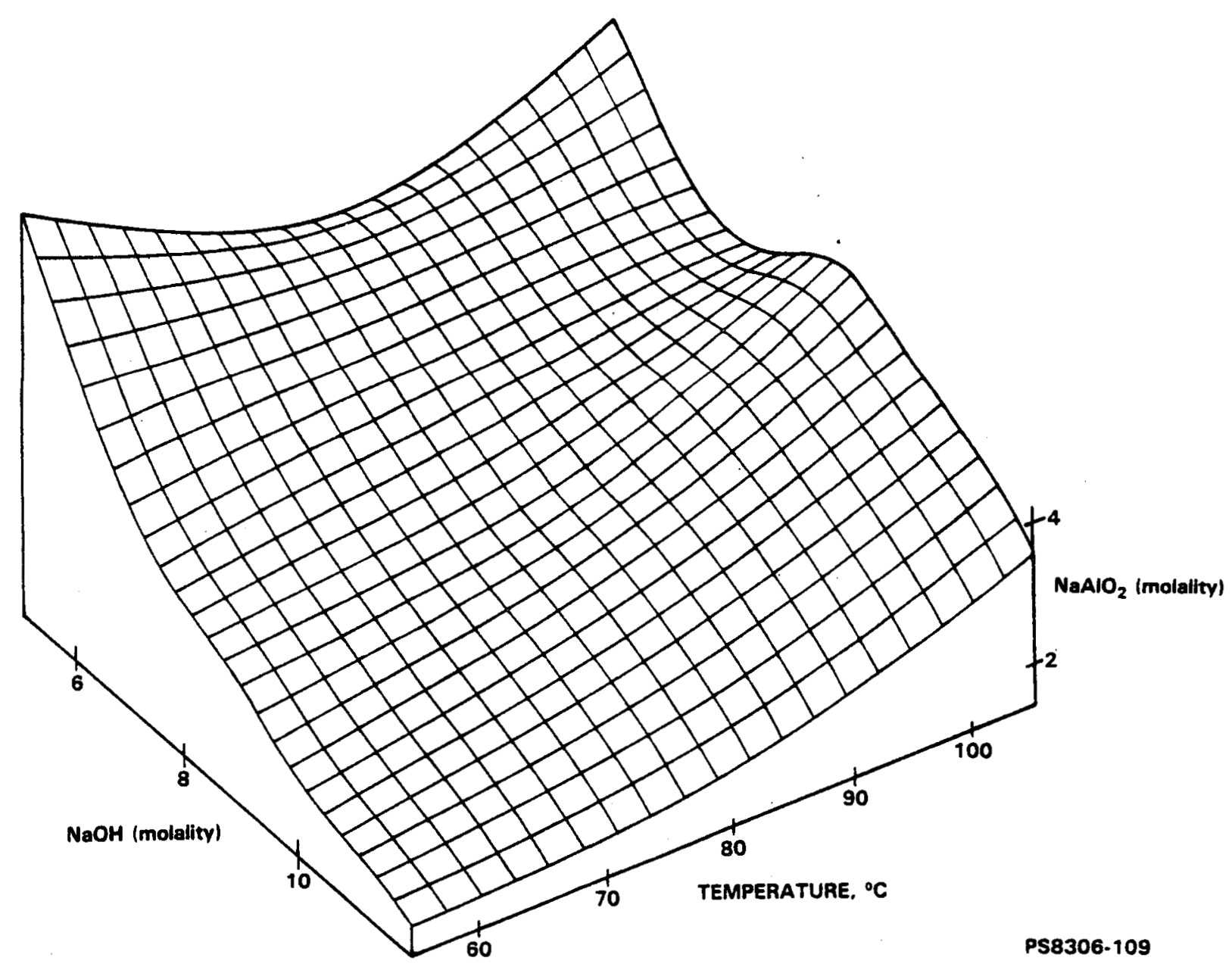

FIGURE 7. Sodium Aluminate Solubility as a Function of Temperature and Hydroxide Concentrations. 
RHO-RE-ST-14 P

TABLE 9. Sodium Aluminate Solubility Equations.

Molality Units

Fu11 equation:

$$
\begin{gathered}
{\left[\mathrm{NaAlO}_{2}\right]=9.359-0.0899(\text { TEMP })-0.567[\mathrm{OH}]+0.000629(\text { TEMP })^{2}} \\
+0.00304(\mathrm{TEMP})[\mathrm{OH}]-0.00534\left[\mathrm{NO}_{3}\right]\left[\mathrm{NO}_{2}\right] \\
\mathrm{R}^{2}=0.9429 \quad \text { Std. Error }=0.2202
\end{gathered}
$$

Simplified equation:

$$
\begin{aligned}
{\left[\mathrm{NaAlO}_{2}\right]=} & 6.471-0.671[\mathrm{OH}]-0.00598\left[\mathrm{NO}_{3}\right]\left[\mathrm{NO}_{2}\right]+0.00424(\mathrm{TEMP})[\mathrm{OH}] \\
& R^{2}=0.8914 \quad \text { Std. Error }=0.3074
\end{aligned}
$$

Valid Ranges:

TEMP from $60^{\circ}$ to $100^{\circ} \mathrm{C}$

$\mathrm{OH}$ from $5.0 \mathrm{~m}$ to $11.5 \mathrm{~m}$

$\mathrm{NO}_{2}$ from $3.7 \mathrm{~m}$ to $14.5 \mathrm{~m}$

$\mathrm{NO}_{3}$ from $3.0 \mathrm{~m}$ to $12.0 \mathrm{~m}$

\section{Molarity Unit:s}

Full equation:

$$
\begin{gathered}
{\left[\mathrm{NaAlO}_{2}\right]=5.304-0.0550(\text { TEMP })-0.502[\mathrm{OH}]+0.000413(\mathrm{TEMP})^{2}} \\
+0.00282(\mathrm{TEMP})[\mathrm{OH}]-0.00189(\mathrm{TEMP})\left[\mathrm{NO}_{3}\right]-0.00150(\mathrm{TEMP})\left[\mathrm{NO}_{2}\right] \\
\mathrm{R}^{2}=0.8529 \quad \text { Std. Error }=0.1472
\end{gathered}
$$

Simplified equation:

$$
\begin{aligned}
& {\left[\mathrm{NaAlO}_{2}\right]=2.386-0.0482\left[\mathrm{NO}_{3}\right]\left[\mathrm{NO}_{2}\right]-0.0378[\mathrm{OH}]^{2}+0.0000695(\mathrm{TEMP})^{2}} \\
& \qquad \mathrm{R}^{2}=0.7507 \quad \text { Std. Error }=0.2031 \\
& \text { Valid Ranges: } \\
& \text { TEMP from } 600 \text { to } 100{ }^{\circ} \mathrm{C} \\
& \mathrm{OH} \text { from } 2.0 \mathrm{M} \text { to } 6.5 \mathrm{M} \\
& \mathrm{NO}_{2} \text { from } 2 . \overline{\mathrm{M}} \text { to } 6.2 \mathrm{M} \\
& \mathrm{NO}_{3} \text { from } 1.7 \underline{\mathrm{M}} \text { to } 5.0 \mathrm{M}
\end{aligned}
$$


TABLE 10. Changes in Sodium Aluminate Solubility.

\begin{tabular}{l|c|c}
\hline \multirow{2}{*}{$\begin{array}{c}\text { Change in } \\
\text { variable (1\%) }\end{array}$} & \multicolumn{2}{|c}{$\begin{array}{c}\text { Percentage } \\
\text { change in NaAl0 } 2\end{array}$} \\
\cline { 2 - 3 } & Molality & Molarity \\
\hline Temperature & 1.1 & 0.4 \\
Hydroxide & -1.0 & -0.8 \\
Nitrite & -0.1 & -0.4 \\
Aluminate & -0.1 & -0.3 \\
\hline
\end{tabular}

Figure 8 is a representation of the sodium aluminate solubility equation in molarity units. This figure is not quite as straightforward as the corresponding $\mathrm{NaNO}_{3}$ and $\mathrm{NaNO}_{2}$ figures, but it is useful in pointing out some features of the equation. Note how the temperature lines invert in going from saturated solution (in $\mathrm{NaNO}_{3}$ and $\mathrm{NaNO}_{2}$ ) to half-saturated. That is, solubility of $\mathrm{NaAlO}_{2}$ generally increases with decreasing temperature in solutions saturated in $\mathrm{NaNO}_{3}$ and $\mathrm{NaNO}_{2}$, while the reverse is true in the half-saturated solutions. As the temperature increases, the amounts of $\mathrm{NaNO}_{3}$ and $\mathrm{NaNO}_{2}$ in the saturated solution increase rapidly (strong temperature responses, Tables 6 and 8 ). Since nitrate and nitrite concentrations both have rather strong inverse effects on $\mathrm{NaAlO}_{2}$ solubility (Table 10), they override the modest temperature effect, and the net result is lower $\mathrm{NaAlO}_{2}$ solubility. Thus, the molarity regression equation contains strong (TEMP) $\left[\mathrm{NO}_{3}\right]$ and (TEMP) $\left[\mathrm{NO}_{2}\right]$ interaction terms not present in the equations for nitrate and nitrite.

\section{DENSITY}

The densities of all solutions were measured at temperature using pycnometers. Some of the data were regressed so that solution density could be predicted. About 50 data points were randomily chosen for this regression. This sample is large enough to ensure that the equations are representative of the data. The handbook values of water density at the temperatures of interest were also included in the data base for the regression. The water data were added so that the regression constant would be closer to that of pure water. Adding the water data did not appreciably affect the accuracy of the equations in the concentration range of interest. Regression equations were derived for both molarity and molality concentration units, and are shown in Table 11. The equations fit the data very we11. The regression coefficient, $R^{2}$, was about 0.98 for both equations. The equations were also tested on data that were not part of the original regression data set. The test data demonstrated an acceptable fit. 


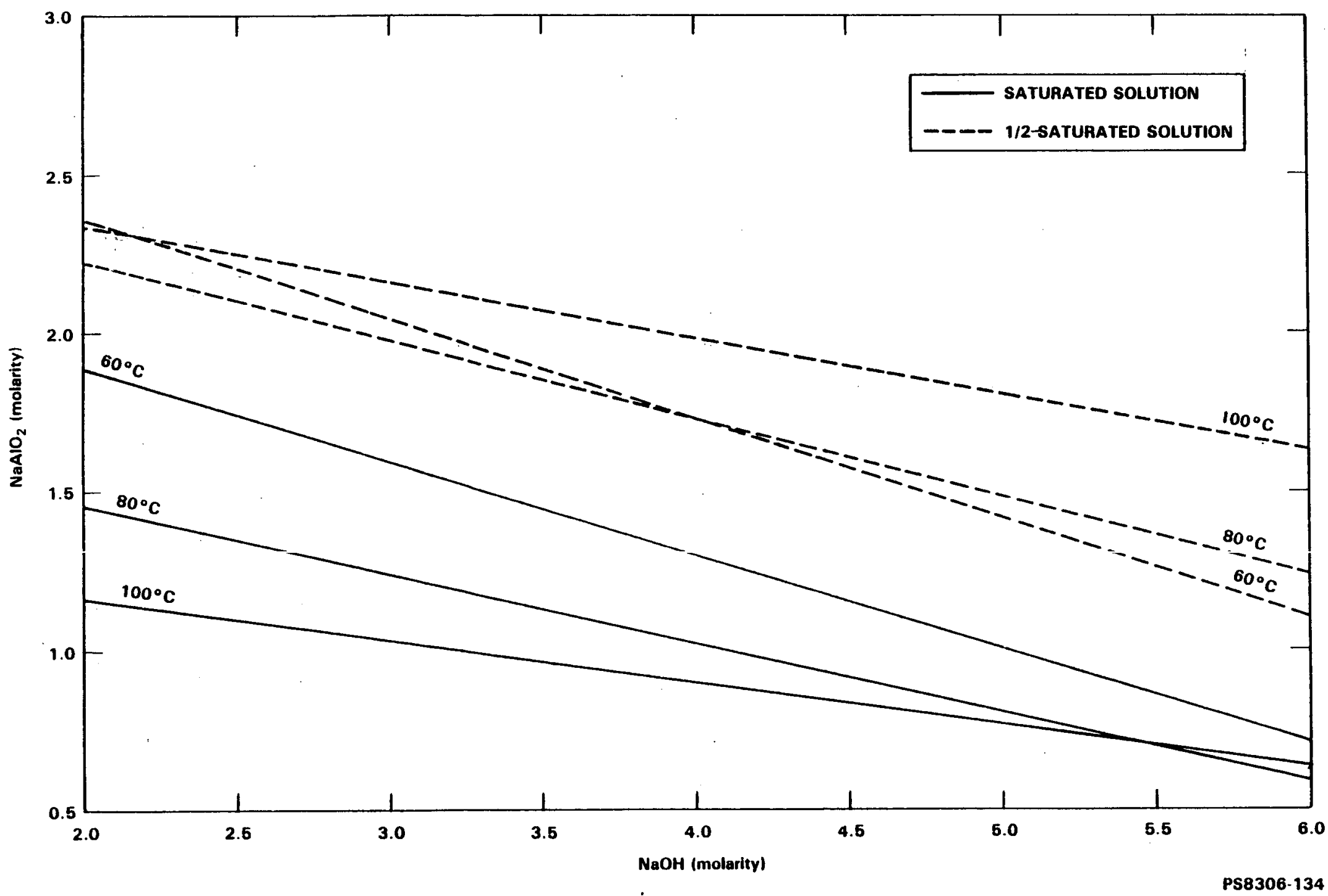

FIGURE 8. Sodium Aluminate Solubility. 
TABLE 11. Density Equations

Molality Units:

$$
\begin{aligned}
\text { Density }= & 1.137+0.0240\left[\mathrm{NO}_{2}\right]-0.00189(\mathrm{TEMP})-0.00134\left[\mathrm{NO}_{3}\right]\left[\mathrm{NO}_{2}\right] \\
& +0.0183\left(\left[\mathrm{AlO}_{2}\right]+[\mathrm{OH}]+\left[\mathrm{NO}_{3}\right]+\left[\mathrm{NO}_{2}\right]\right)
\end{aligned}
$$

Molarity Units:

$$
\begin{aligned}
\text { Density }= & 1.017+0.0587\left[\mathrm{AlO}_{2}\right]-0.01943[\mathrm{OH}]-0.000505\left(\mathrm{TEMP}^{-0}\right) \\
& +0.0459\left(\left[\mathrm{AlO}_{2}\right]+[\mathrm{OH}]+\left[\mathrm{NO}_{3}\right]+\left[\mathrm{NO}_{2}\right]\right)-0.000883\left[\mathrm{NO}_{3}\right]\left[\mathrm{NO}_{2}\right]
\end{aligned}
$$

\section{OTHER EFFECTS}

Certain nitrate/nitrite runs yielded cloudy solutions. Microscopic examination showed that the cloudiness was due to sodium carbonate. These experiments were repeated with the sodium carbonate and sodium sulfate omitted from the matrix. Several runs were made to determine whether the change in matrix would have any effect. The data showed that, within the accuracy of the experiment, the carbonate and sulfate do not measurably affect the solubility of sodium nitrate and sodium nitrite at the concentrations that were studied.

The organic components were thought to have some effect on the solubilities. Several runs were made to test them. No measurable effect on nitrate/nitrite solubility was found in the tests that were run. Sodium aluminate solubility, however, was affected. At low hydroxide concentrations, the runs that had organics present had a lower concentration of sodium aluminate than those with no organics. The data showed that this effect decreased as the concentration of hydroxide increased. These findings were consistent with earlier studies.

\section{IMPLICATIONS OF THIS STUDY}

One of the major results of this study is the discovery that temperature has a much larger effect than was previously believed. In addition, the solubility of sodium nitrite was much larger at all temperatures than had been expected. Previous understanding was ihat sodium hydroxide concentration had the strongest effect on solubilities. It was believed that a knowledge of hydroxide concentration alone would be sufficient to allow prediction of the solubilities of the other constituents. 
While hydroxide is a major factor, the more complex relationships can now be taken into account. Figures 5,6 , and 8 show the phase diagrams in two-dimensional plots. A computer code has also been written to calculate component solubilities based on the new relationships.

The computer code has shown that the study will not result in any new waste management implications. However, the study does explain several of the past occurrences that were not understood. The better understanding that the study has provided will allow for better control of the conçentration process. 


\section{ACKNOWLEDGMENTS}

This work could not have been completed without the help of several people. Rose Cleavenger performed most of the laboratory work. Her dedication, care, and superlative technique made possible the high degree of accuracy that we are able to report. Dr. Evan Jenson developed and refined the thermotitration technique for aluminate and hydroxide analyses, and analyzed as many as 50 solutions a day with better than one percent accuracy. Without his skill and determination, those analyses would have been the limiting factor in the accuracy of our results. Dr. Al Liebetrau provided a great deal of help in both the experimental design and the statistical treatment of results. His discussions with the authors during the planning stages helped immeasurably to clarify the author's original concept and developed it into a workable, elegant strategy.

\section{REFERENCES}

1. G. S. Barney, Vapor-Liquid-Solid Phase Equilibria of Radioactive Sodium Salt Wastes at Hanford, ARH-ST-133, AtTantic Richfield Hanford Company, Richland, Washington (January 1976).

2. J. C. Petrie; R. I. Donovan; R. E. Van Der Cook; W. R. Christensen, "Putting Evaporators to Work: Vacuum Evaporator--Crystallizer Handles Radioactive Waste," Chemical Engineering Progress, Vol 72, No. 4, pp 65-71 (Apri1 1976). 
RHO-RE-ST-14 P

APPENDIX A

PHASE DIAGRAM, COMPLETE; CONCENTRATIONS IN MOLALITIES

Sheet 1 of 7

\begin{tabular}{|c|c|c|c|c|c|c|c|}
\hline \multirow{2}{*}{$\begin{array}{l}\text { Run } \\
\text { No. }\end{array}$} & \multirow{2}{*}{ Variable } & \multicolumn{4}{|c|}{ Concentration } & \multirow{2}{*}{$\begin{array}{c}\text { Temper- } \\
\text { ature }\end{array}$} & \multirow{2}{*}{$\begin{array}{l}\text { Specific } \\
\text { gravity }\end{array}$} \\
\hline & & $\mathrm{NO}_{3}$ & $\mathrm{NO}_{2}$ & $\mathrm{~A} 1 \mathrm{O}_{2}$ & $\mathrm{OH}$ & & \\
\hline $\begin{array}{l}A X-1 \\
A X-1 R \\
A X-1 P \\
A X-1 Q \\
A X-2 \\
A X-2 R \\
A X-2 S \\
A X-3 \\
A X-3 R \\
A X-4 \\
A X-4 R \\
A X-4 P \\
A X-4 Q\end{array}$ & $\begin{array}{l}\mathrm{NO}_{3} \\
\mathrm{NO}_{3} \\
\mathrm{NO}_{3} \\
\mathrm{NO} \\
\mathrm{NO}_{3} \\
\mathrm{NO}_{3} \\
\mathrm{NO} 3 \\
\mathrm{NO} \\
\mathrm{NO} \\
\mathrm{NO} \\
\mathrm{NO}_{3} \\
\mathrm{NO}_{3} \\
\mathrm{NO}_{3}\end{array}$ & $\begin{array}{l}5.85 \\
5.84 \\
5.78 \\
5.78 \\
5.85 \\
5.98 \\
5.88 \\
5.63 \\
5.70 \\
5.74 \\
5.73 \\
5.71 \\
5.68\end{array}$ & $\begin{array}{l}7.37 \\
7.37 \\
7.37 \\
7.37 \\
7.36 \\
7.36 \\
7.36 \\
4.91 \\
4.91 \\
4.91 \\
4.91 \\
4.91 \\
4.91\end{array}$ & $\begin{array}{l}1.99 \\
1.99 \\
1.94 \\
1.94 \\
1.20 \\
1.20 \\
1.20 \\
1.99 \\
1.99 \\
1.20 \\
1.20 \\
1.18 \\
1.18\end{array}$ & $\begin{array}{l}8.82 \\
8.82 \\
8.89 \\
8.89 \\
8.89 \\
8.89 \\
8.89 \\
8.82 \\
8.82 \\
8.89 \\
8.89 \\
8.92 \\
8.92\end{array}$ & $\begin{array}{l}60 \\
60 \\
60 \\
60 \\
60 \\
60 \\
60 \\
60 \\
60 \\
60 \\
60 \\
60 \\
60\end{array}$ & $\begin{array}{l}1.574 \\
1.596 \\
1.554 \\
1.558 \\
1.578 \\
1.547 \\
1.541 \\
1.539 \\
1.556 \\
1.543 \\
1.522 \\
1.513 \\
1.508\end{array}$ \\
\hline $\begin{array}{l}A X-5 \\
A X-5 R \\
A X-5 P \\
A X-5 Q \\
A X-6 \\
A X-6 R \\
A X-7 \\
A X-7 R \\
A X-8 \\
A X-8 R \\
A X-8 P\end{array}$ & $\begin{array}{l}\mathrm{NO}_{2} \\
\mathrm{NO}_{2} \\
\mathrm{NO} 2 \\
\mathrm{NO}_{2} \\
\mathrm{NO}_{2} \\
\mathrm{NO} 2 \\
\mathrm{NO} 2 \\
\mathrm{NO} 2 \\
\mathrm{NO} 2 \\
\mathrm{NO} 2 \\
\mathrm{NO} 2\end{array}$ & $\begin{array}{l}5.48 \\
5.48 \\
5.48 \\
5.48 \\
5.48 \\
5.48 \\
3.43 \\
3.43 \\
3.43 \\
3.43 \\
3.43\end{array}$ & $\begin{array}{l}7.80 \\
7.85 \\
7.81 \\
7.81 \\
8.03 \\
7.96 \\
7.75 \\
7.77 \\
7.89 \\
7.88 \\
7.70\end{array}$ & $\begin{array}{l}1.99 \\
1.99 \\
1.94 \\
1.94 \\
1.20 \\
1.20 \\
1.99 \\
1.99 \\
1.20 \\
1.20 \\
1.18\end{array}$ & $\begin{array}{l}8.82 \\
8.82 \\
8.89 \\
8.89 \\
8.89 \\
8.89 \\
8.82 \\
8.82 \\
8.89 \\
8.89 \\
8.92\end{array}$ & $\begin{array}{l}60 \\
60 \\
60 \\
60 \\
60 \\
60 \\
60 \\
60 \\
60 \\
60 \\
60\end{array}$ & $\begin{array}{l}1.584 \\
1.561 \\
1.557 \\
1.553 \\
1.586 \\
1.556 \\
1.567 \\
1.532 \\
1.526 \\
1.572 \\
1.509\end{array}$ \\
\hline $\begin{array}{l}A X-9 A \\
A X-9 B \\
A X-10 A \\
A X-10 B \\
A X-11 A \\
A X-11 B \\
A X-12 A \\
A X-12 B \\
A X-13 \\
A X-14 \\
A X-15 \\
A X-16\end{array}$ & $\begin{array}{l}A 10_{2} \\
A 10_{2} \\
A 102 \\
A 10_{2} \\
A 10_{2} \\
A 10_{2} \\
A 10_{2} \\
A 10_{2} \\
A 10_{2} \\
A 10_{2} \\
A 10_{2} \\
A 10_{2}\end{array}$ & $\begin{array}{l}5.48 \\
5.48 \\
5.48 \\
5.48 \\
3.43 \\
3.43 \\
3.43 \\
3.43 \\
5.48 \\
5.48 \\
3.43 \\
3.43\end{array}$ & $\begin{array}{l}7.36 \\
7.36 \\
4.91 \\
4.91 \\
7.36 \\
7.36 \\
4.91 \\
4.91 \\
7.36 \\
4.91 \\
7.36 \\
4.91\end{array}$ & $\begin{array}{l}2.52 \\
2.54 \\
2.62 \\
2.55 \\
2.71 \\
2.45 \\
2.62 \\
2.75 \\
2.40 \\
2.52 \\
2.46 \\
2.67\end{array}$ & $\begin{array}{l}8.85 \\
8.85 \\
8.85 \\
8.85 \\
8.85 \\
8.85 \\
8.85 \\
8.85 \\
8.85 \\
8.85 \\
8.85 \\
8.85\end{array}$ & $\begin{array}{l}60 \\
60 \\
60 \\
60 \\
60 \\
60 \\
60 \\
60 \\
60 \\
60 \\
60 \\
60\end{array}$ & $\begin{array}{l}1.54 \\
1.54 \\
1.53 \\
1.53 \\
1.52 \\
1.52 \\
1.65 \\
1.50 \\
1.55 \\
1.53 \\
1.52 \\
1.51\end{array}$ \\
\hline
\end{tabular}


RHO-RE-ST-14 P

Sheet 2 of 7

\begin{tabular}{|c|c|c|c|c|c|c|c|}
\hline \multirow{2}{*}{$\begin{array}{l}\text { Run } \\
\text { No. }\end{array}$} & \multirow{2}{*}{ Variable } & \multicolumn{4}{|c|}{ Concentration } & \multirow{2}{*}{$\begin{array}{l}\text { Temper- } \\
\text { ature }\end{array}$} & \multirow{2}{*}{$\begin{array}{l}\text { Specific } \\
\text { gravity }\end{array}$} \\
\hline & & $\mathrm{NO}_{3}$ & $\mathrm{NO}_{2}$ & $\mathrm{AlO}_{2}$ & $\mathrm{OH}$ & & \\
\hline $\begin{array}{l}A Y-1 \\
A Y-1 R \\
A Y-1 E \\
A Y-1 F \\
A Y-01 \\
A Y-2 \\
A Y-3 \\
A Y-3 R \\
A Y-3 E \\
A Y-03 \\
A Y-3 M \\
A Y-4 \\
A Y-4 R \\
A Y-4 M \\
A Y-4 N\end{array}$ & $\begin{array}{l}\mathrm{NO}_{3} \\
\mathrm{NO}_{3} \\
\mathrm{NO}_{3} \\
\mathrm{NO}_{3} \\
\mathrm{NO}_{3} \\
\mathrm{NO}_{3} \\
\mathrm{NO}_{3} \\
\mathrm{NO}_{3} \\
\mathrm{NO}_{3} \\
\mathrm{NO} \\
\mathrm{NO}_{3} \\
\mathrm{NO}_{3} \\
\mathrm{NO}_{3} \\
\mathrm{NO}_{3} \\
\mathrm{NO}_{3}\end{array}$ & $\begin{array}{l}6.92 \\
6.86 \\
6.96 \\
6.96 \\
6.97 \\
7.08 \\
6.91 \\
6.88 \\
7.05 \\
6.97 \\
6.93 \\
7.28 \\
7.35 \\
7.13 \\
7.23\end{array}$ & $\begin{array}{l}9.13 \\
9.13 \\
9.13 \\
9.13 \\
9.15 \\
9.22 \\
4.95 \\
4.95 \\
4.96 \\
4.96 \\
7.78 \\
5.00 \\
4.95 \\
7.86 \\
7.99\end{array}$ & $\begin{array}{l}1.92 \\
1.92 \\
1.98 \\
1.98 \\
2.68 \\
1.14 \\
1.92 \\
1.92 \\
1.98 \\
2.68 \\
1.92 \\
1.14 \\
1.14 \\
1.14 \\
1.14\end{array}$ & $\begin{array}{l}5.27 \\
5.27 \\
5.52 \\
5.52 \\
5.31 \\
5.26 \\
5.27 \\
5.27 \\
5.52 \\
5.31 \\
5.27 \\
5.26 \\
5.27 \\
5.26 \\
5.27\end{array}$ & $\begin{array}{l}60 \\
60 \\
60 \\
60 \\
60 \\
60 \\
60 \\
60 \\
60 \\
60 \\
60 \\
60 \\
60 \\
60 \\
60\end{array}$ & $\begin{array}{l}1.554 \\
1.554 \\
1.558 \\
1.546 \\
1.559 \\
1.551 \\
1.520 \\
1.534 \\
1.515 \\
1.526 \\
1.544 \\
1.514 \\
1.501 \\
1.546 \\
1.531\end{array}$ \\
\hline $\begin{array}{l}A Y-5 \\
A Y-5 R \\
A Y-5 E \\
A Y-5 F \\
A Y-5 G \\
A Y-05 \\
A Y-6 \\
A Y-6 R \\
A Y-7 \\
A Y-07 \\
A Y-8 \\
A Y-8 R \\
A Y-8 E\end{array}$ & $\begin{array}{l}\mathrm{NO}_{2} \\
\mathrm{NO}_{2} \\
\mathrm{NO}_{2} \\
\mathrm{NO}_{2} \\
\mathrm{NO}_{2} \\
\mathrm{NO}_{2} \\
\mathrm{NO}_{2} \\
\mathrm{NO}_{2} \\
\mathrm{NO}_{2} \\
\mathrm{NO}_{2} \\
\mathrm{NO}_{2} \\
\mathrm{NO}_{2} \\
\mathrm{NO}_{2}\end{array}$ & $\begin{array}{l}6.32 \\
6.32 \\
6.32 \\
6.32 \\
6.32 \\
6.33 \\
6.38 \\
6.38 \\
3.98 \\
3.99 \\
4.02 \\
4.02 \\
3.98\end{array}$ & $\begin{array}{l}9.57 \\
9.55 \\
9.63 \\
9.59 \\
9.57 \\
9.62 \\
9.86 \\
9.87 \\
9.56 \\
9.59 \\
9.96 \\
9.90 \\
9.79\end{array}$ & $\begin{array}{l}1.92 \\
1.92 \\
1.98 \\
1.98 \\
1.98 \\
2.68 \\
1.14 \\
1.14 \\
1.92 \\
2.68 \\
1.14 \\
1.14 \\
1.16\end{array}$ & $\begin{array}{l}5.27 \\
5.27 \\
5.52 \\
5.52 \\
5.52 \\
5.31 \\
5.26 \\
5.26 \\
5.27 \\
5.31 \\
5.26 \\
5.26 \\
5.39\end{array}$ & $\begin{array}{l}60 \\
60 \\
60 \\
60 \\
60 \\
60 \\
60 \\
60 \\
60 \\
60 \\
60 \\
60 \\
60\end{array}$ & $\begin{array}{l}1.575 \\
1.5599 \\
1.549 \\
1.547 \\
1.543 \\
1.558 \\
1.535 \\
1.548 \\
1.540 \\
1.531 \\
1.506 \\
1.495 \\
1.518\end{array}$ \\
\hline $\begin{array}{l}A Y-9 B \\
A Y-9 D \\
A Y-9 E \\
A Y-10 B \\
A Y-10 C \\
A Y-10 D \\
A Y-11 B \\
A Y-11 D \\
A Y-12 B \\
A Y-12 D \\
A Y-12 E\end{array}$ & $\begin{array}{l}A 10_{2} \\
A 10_{2} \\
A 10_{2} \\
A 10_{2} \\
A 10_{2} \\
A 10_{2} \\
A 10_{2} \\
A 10_{2} \\
A 10_{2} \\
A 10_{2} \\
A 10_{2}\end{array}$ & $\begin{array}{l}6.26 \\
6.26 \\
6.26 \\
6.26 \\
6.26 \\
6.26 \\
3.95 \\
3.95 \\
3.95 \\
3.95 \\
3.95\end{array}$ & $\begin{array}{l}9.05 \\
9.05 \\
9.05 \\
4.91 \\
4.91 \\
4.91 \\
9.05 \\
9.05 \\
4.91 \\
4.91 \\
4.91\end{array}$ & $\begin{array}{l}4.43 \\
3.76 \\
3.90 \\
3.95 \\
3.90 \\
3.84 \\
3.92 \\
4.35 \\
5.49 \\
4.42 \\
4.69\end{array}$ & $\begin{array}{l}5.22 \\
5.22 \\
5.22 \\
5.22 \\
5.22 \\
5.22 \\
5.22 \\
5.22 \\
5.22 \\
5.22 \\
5.22\end{array}$ & $\begin{array}{l}60 \\
60 \\
60 \\
60 \\
60 \\
60 \\
60 \\
60 \\
60 \\
60 \\
60\end{array}$ & $\begin{array}{l}1.53 \\
1.57 \\
1.57 \\
1.54 \\
1.55 \\
1.54 \\
1.55 \\
1.56 \\
1.54 \\
1.49 \\
1.51\end{array}$ \\
\hline
\end{tabular}


RHO-RE-ST-14 P

Sheet 3 of $;$

\begin{tabular}{|c|c|c|c|c|c|c|c|}
\hline \multirow{2}{*}{$\begin{array}{l}\text { Run } \\
\text { No. }\end{array}$} & \multirow{2}{*}{ Variable } & \multicolumn{4}{|c|}{ Concentration } & \multirow{2}{*}{$\begin{array}{l}\text { Temper- } \\
\text { ature }\end{array}$} & \multirow{2}{*}{$\begin{array}{l}\text { Specific } \\
\text { gravity }\end{array}$} \\
\hline & & $\mathrm{NO}_{3}$ & $\mathrm{NO}_{2}$ & $\mathrm{AlO}_{2}$ & $\mathrm{OH}$ & & \\
\hline $\begin{array}{l}A Z-1 \\
A Z-1 R \\
A Z-1 S \\
A Z-1 E \\
A Z-2 \\
A Z-3 \\
A Z-3 R \\
A Z-3 E \\
A Z-4\end{array}$ & $\begin{array}{l}\mathrm{NO}_{3} \\
\mathrm{NO}_{3} \\
\mathrm{NO}_{3} \\
\mathrm{NO}_{3} \\
\mathrm{NO}_{3} \\
\mathrm{NO}_{3} \\
\mathrm{NO}_{3} \\
\mathrm{NO}_{3} \\
\mathrm{NO}_{3}\end{array}$ & $\begin{array}{l}5.00 \\
4.99 \\
5.09 \\
5.08 \\
5.08 \\
4.82 \\
4.94 \\
4.90 \\
4.93\end{array}$ & $\begin{array}{l}5.31 \\
5.31 \\
5.29 \\
5.29 \\
5.83 \\
3.62 \\
3.61 \\
3.61 \\
3.97\end{array}$ & $\begin{array}{l}1.92 \\
1.92 \\
1.89 \\
1.86 \\
1.14 \\
1.92 \\
1.89 \\
1.86 \\
1.14\end{array}$ & $\begin{array}{l}11.30 \\
11.30 \\
11.17 \\
11.17 \\
11.25 \\
11.30 \\
11.17 \\
11.17 \\
11.25\end{array}$ & $\begin{array}{l}60 \\
60 \\
60 \\
60 \\
60 \\
60 \\
60 \\
60 \\
60\end{array}$ & $\begin{array}{l}1.546 \\
1.551 \\
1.546 \\
1.541 \\
1.540 \\
1.527 \\
1.529 \\
1.520 \\
1.525\end{array}$ \\
\hline $\begin{array}{l}A Z-5 \\
A Z-5 R \\
A Z-5 S \\
A Z-5 E \\
A Z-6 \\
A Z-6 R \\
A Z-7 \\
A Z-7 R \\
A Z-7 E \\
A Z-8 \\
A Z-8 R\end{array}$ & $\begin{array}{l}\mathrm{NO}_{2} \\
\mathrm{NO}_{2} \\
\mathrm{NO}_{2} \\
\mathrm{NO}_{2} \\
\mathrm{NO}_{2} \\
\mathrm{NO}_{2} \\
\mathrm{NO}_{2} \\
\mathrm{NO}_{2} \\
\mathrm{NO}_{2} \\
\mathrm{NO}_{2} \\
\mathrm{NO}_{2}\end{array}$ & $\begin{array}{l}4.31 \\
4.31 \\
4.29 \\
4.29 \\
4.73 \\
4.73 \\
3.14 \\
3.12 \\
3.12 \\
3.44 \\
3.44\end{array}$ & $\begin{array}{l}6.65 \\
6.69 \\
6.79 \\
6.78 \\
6.82 \\
6.75 \\
6.50 \\
6.69 \\
6.68 \\
6.69 \\
6.64\end{array}$ & $\begin{array}{l}1.92 \\
1.92 \\
1.89 \\
1.86 \\
1.14 \\
1.14 \\
1.92 \\
1.89 \\
1.86 \\
1.14 \\
1.14\end{array}$ & $\begin{array}{l}11.30 \\
11.30 \\
11.17 \\
11.17 \\
11.25 \\
11.25 \\
11.30 \\
11.17 \\
11.17 \\
11.25 \\
11.25\end{array}$ & $\begin{array}{l}60 \\
60 \\
60 \\
60 \\
60 \\
60 \\
60 \\
60 \\
60 \\
60 \\
60\end{array}$ & $\begin{array}{l}1.551 \\
1.548 \\
1.550 \\
1.547 \\
1.547 \\
1.552 \\
1.534 \\
1.531 \\
1.530 \\
1.525 \\
1.525\end{array}$ \\
\hline $\begin{array}{l}A Z-9 A \\
A Z-9 B \\
A Z-10 A \\
A Z-10 B \\
A Z-11 A \\
A Z-11 B \\
A Z-12 A \\
A Z-12 B\end{array}$ & $\begin{array}{l}A 10_{2} \\
A 10_{2} \\
A 10_{2} \\
A 10_{2} \\
A 10_{2} \\
A 10_{2} \\
A 10_{2} \\
A 10_{2}\end{array}$ & $\begin{array}{l}4.50 \\
4.50 \\
4.50 \\
4.50 \\
3.25 \\
3.25 \\
3.25 \\
3.25\end{array}$ & $\begin{array}{l}5.50 \\
5.50 \\
3.75 \\
3.75 \\
5.50 \\
5.50 \\
3.75 \\
3.75\end{array}$ & $\begin{array}{l}1.89 \\
1.79 \\
1.83 \\
1.80 \\
1.80 \\
1.74 \\
1.85 \\
2.09\end{array}$ & $\begin{array}{l}11.28 \\
11.28 \\
11.28 \\
11.28 \\
11.28 \\
11.28 \\
11.28 \\
11.28\end{array}$ & $\begin{array}{l}60 \\
60 \\
60 \\
60 \\
60 \\
60 \\
60 \\
60\end{array}$ & $\begin{array}{l}1.53 \\
1.53 \\
1.51 \\
1.51 \\
1.51 \\
1.51 \\
1.49 \\
1.50\end{array}$ \\
\hline $\begin{array}{l}B X-1 \\
B X-1 R \\
B X-1 P \\
B X-1 Q \\
B X-1 T \\
B X-2 \\
B X-3 \\
B X-4 \\
B X-4 P \\
B X-4 Q \\
B X-4 M \\
B X-4 N\end{array}$ & $\begin{array}{l}\mathrm{NO}_{3} \\
\mathrm{NO}_{3} \\
\mathrm{NO}_{3} \\
\mathrm{NO}_{3} \\
\mathrm{NO}_{3} \\
\mathrm{NO}_{3} \\
\mathrm{NO}_{3} \\
\mathrm{NO}_{3} \\
\mathrm{NO}_{3} \\
\mathrm{NO}_{3} \\
\mathrm{NO}_{3} \\
\mathrm{NO}_{3}\end{array}$ & $\begin{array}{l}8.82 \\
8.57 \\
8.71 \\
8.65 \\
8.67 \\
8.75 \\
8.43 \\
8.28 \\
8.48 \\
8.43 \\
8.22 \\
8.28\end{array}$ & $\begin{array}{r}10.28 \\
10.28 \\
10.28 \\
10.28 \\
10.20 \\
10.26 \\
7.48 \\
7.47 \\
7.47 \\
7.42 \\
4.91 \\
4.88\end{array}$ & $\begin{array}{l}1.99 \\
1.99 \\
1.94 \\
1.94 \\
1.94 \\
1.19 \\
1.99 \\
1.19 \\
1.17 \\
1.17 \\
1.19 \\
1.17\end{array}$ & $\begin{array}{l}8.82 \\
8.82 \\
8.89 \\
8.89 \\
8.89 \\
8.87 \\
8.82 \\
8.87 \\
8.90 \\
8.90 \\
8.87 \\
8.90\end{array}$ & $\begin{array}{l}80 \\
80 \\
80 \\
80 \\
80 \\
80 \\
80 \\
80 \\
80 \\
80 \\
80 \\
80\end{array}$ & $\begin{array}{l}1.604 \\
1.640 \\
1.589 \\
1.602 \\
1.589 \\
1.604 \\
1.580 \\
1.595 \\
1.558 \\
1.571 \\
1.554 \\
1.554\end{array}$ \\
\hline
\end{tabular}


RHO-RE-ST-14 P

Sheet 4 of 7

\begin{tabular}{|c|c|c|c|c|c|c|c|}
\hline \multirow{2}{*}{$\begin{array}{l}\text { Run } \\
\text { No. }\end{array}$} & \multirow{2}{*}{ Variable } & \multicolumn{4}{|c|}{ Concentration } & \multirow{2}{*}{$\begin{array}{c}\text { Temper- } \\
\text { ature }\end{array}$} & \multirow{2}{*}{$\begin{array}{l}\text { Specific } \\
\text { gravity }\end{array}$} \\
\hline & & $\mathrm{NO}_{3}$ & $\mathrm{NO}_{2}$ & $\mathrm{~A}^{10} 0_{2}$ & $\mathrm{OH}$ & & \\
\hline $\begin{array}{l}B X-5 \\
B X-5 R \\
B X-5 S \\
B X-5 P \\
B X-6 \\
B X-6 R \\
B X-6 P \\
B X-6 Q \\
B X-7 \\
B X-7 R \\
B X-8 \\
B X-8 R \\
B X-8 P \\
B X-8 M \\
B X-8 N\end{array}$ & $\begin{array}{l}\mathrm{NO}_{2} \\
\mathrm{NO}_{2} \\
\mathrm{NO}_{2} \\
\mathrm{NO}_{2} \\
\mathrm{NO}_{2} \\
\mathrm{NO}_{2} \\
\mathrm{NO}_{2} \\
\mathrm{NO}_{2} \\
\mathrm{NO}_{2} \\
\mathrm{NO}_{2} \\
\mathrm{NO}_{2} \\
\mathrm{NO}_{2} \\
\mathrm{NO}_{2} \\
\mathrm{NO}_{2} \\
\mathrm{NO}_{2}\end{array}$ & $\begin{array}{l}8.18 \\
8.18 \\
8.07 \\
8.12 \\
8.17 \\
8.17 \\
8.17 \\
8.17 \\
5.59 \\
5.59 \\
5.58 \\
5.58 \\
5.58 \\
3.43 \\
3.41\end{array}$ & $\begin{array}{l}11.83 \\
11.06 \\
11.28 \\
11.51 \\
11.61 \\
11.79 \\
11.53 \\
11.45 \\
11.09 \\
11.37 \\
11.47 \\
11.44 \\
11.24 \\
10.65 \\
10.91\end{array}$ & $\begin{array}{l}1.99 \\
1.99 \\
1.99 \\
1.94 \\
1.19 \\
1.19 \\
1.17 \\
1.17 \\
1.99 \\
1.99 \\
1.19 \\
1.19 \\
1.17 \\
1.19 \\
1.17\end{array}$ & $\begin{array}{l}8.83 \\
8.82 \\
8.82 \\
8.89 \\
8.87 \\
8.87 \\
8.90 \\
8.90 \\
8.82 \\
8.82 \\
8.87 \\
8.87 \\
8.90 \\
8.87 \\
8.90\end{array}$ & $\begin{array}{l}80 \\
80 \\
80 \\
80 \\
80 \\
80 \\
80 \\
80 \\
80 \\
80 \\
80 \\
80 \\
80 \\
80 \\
80\end{array}$ & $\begin{array}{l}1.622 \\
1.586 \\
1.615 \\
1.621 \\
1.600 \\
1.572 \\
1.599 \\
1.595 \\
1.602 \\
1.632 \\
1.574 \\
1.604 \\
1.573 \\
1.552 \\
1.550\end{array}$ \\
\hline $\begin{array}{l}B X-9 A \\
B X-9 B \\
B X-9 C \\
B X-10 A \\
B X-10 B \\
B X-10 C \\
B X-11 A \\
B X-11 B \\
B X-12 A \\
B X-12 B \\
B X-12 C \\
B X-13 \\
B X-14 \\
B X-15 \\
B X-16\end{array}$ & $\begin{array}{l}A 10_{2} \\
A 10_{2} \\
A 10_{2} \\
A 10_{2} \\
A 10_{2} \\
A 10_{2} \\
A 10_{2} \\
A 10_{2} \\
A 10_{2} \\
A 10_{2} \\
A 10_{2} \\
A 10_{2} \\
A 10_{2} \\
A 10_{2} \\
A 10_{2}\end{array}$ & $\begin{array}{l}7.99 \\
7.99 \\
7.99 \\
7.99 \\
7.99 \\
7.99 \\
5.46 \\
5.46 \\
5.46 \\
5.46 \\
5.58 \\
8.18 \\
8.18 \\
5.58 \\
5.58\end{array}$ & $\begin{array}{r}10.03 \\
10.03 \\
10.03 \\
7.30 \\
7.30 \\
7.30 \\
10.03 \\
10.03 \\
7.30 \\
7.30 \\
7.47 \\
10.26 \\
7.47 \\
10.26 \\
7.47\end{array}$ & $\begin{array}{l}3.02 \\
2.79 \\
2.76 \\
3.07 \\
2.96 \\
2.94 \\
3.11 \\
2.86 \\
3.36 \\
2.94 \\
3.11 \\
2.91 \\
3.00 \\
3.23 \\
4.28\end{array}$ & $\begin{array}{l}8.85 \\
8.85 \\
8.85 \\
8.85 \\
8.85 \\
8.85 \\
8.85 \\
8.85 \\
8.85 \\
8.85 \\
8.85 \\
8.85 \\
8.85 \\
8.85 \\
8.85\end{array}$ & $\begin{array}{l}80 \\
80 \\
80 \\
80 \\
80 \\
80 \\
80 \\
80 \\
80 \\
80 \\
80 \\
80 \\
80 \\
80 \\
80\end{array}$ & $\begin{array}{l}1.61 \\
1.62 \\
1.60 \\
1.58 \\
1.58 \\
1.60 \\
1.56 \\
1.56 \\
1.54 \\
1.53 \\
1.55 \\
1.60 \\
1.58 \\
1.57 \\
1.55\end{array}$ \\
\hline $\begin{array}{l}B Y-1 \\
B Y-1 R \\
B Y-01 \\
B Y-2 \\
B Y-2 R \\
B Y-3 \\
B Y-03 \\
B Y-4\end{array}$ & $\begin{array}{l}\mathrm{NO}_{3} \\
\mathrm{NO}_{3} \\
\mathrm{NO}_{3} \\
\mathrm{NO}_{3} \\
\mathrm{NO}_{3} \\
\mathrm{NO}_{3} \\
\mathrm{NO}_{3} \\
\mathrm{NO}_{3}\end{array}$ & $\begin{array}{r}9.88 \\
9.98 \\
10.07 \\
10.02 \\
10.06 \\
9.64 \\
9.89 \\
9.97\end{array}$ & $\begin{array}{r}12.22 \\
12.30 \\
12.21 \\
12.35 \\
12.35 \\
8.30 \\
8.30 \\
8.39\end{array}$ & $\begin{array}{l}1.92 \\
1.95 \\
2.67 \\
1.14 \\
1.14 \\
1.92 \\
2.67 \\
1.14\end{array}$ & $\begin{array}{l}5.27 \\
5.40 \\
5.28 \\
5.26 \\
5.26 \\
5.27 \\
5.28 \\
5.26\end{array}$ & $\begin{array}{l}80 \\
80 \\
80 \\
80 \\
80 \\
80 \\
80 \\
80\end{array}$ & $\begin{array}{l}1.638 \\
1.635 \\
1.630 \\
1.624 \\
1.594 \\
1.562 \\
1.577 \\
1.573\end{array}$ \\
\hline $\begin{array}{l}B Y-5 \\
B Y-5 R \\
B Y-05 \\
B Y-6\end{array}$ & $\begin{array}{l}\mathrm{NO}_{2} \\
\mathrm{NO}_{2} \\
\mathrm{NO}_{2} \\
\mathrm{NO}_{2}\end{array}$ & $\begin{array}{l}9.36 \\
9.42 \\
9.35 \\
9.45\end{array}$ & $\begin{array}{l}13.14 \\
13.32 \\
13.48 \\
13.50\end{array}$ & $\begin{array}{l}1.92 \\
1.95 \\
2.67 \\
1.14\end{array}$ & $\begin{array}{l}5.27 \\
5.40 \\
5.28 \\
5.26\end{array}$ & $\begin{array}{l}80 \\
80 \\
80 \\
80\end{array}$ & $\begin{array}{l}1.615 \\
1.628 \\
1.620 \\
1.640\end{array}$ \\
\hline
\end{tabular}


RHO-RE-ST-14 P

Sheet 5 of 7

\begin{tabular}{|c|c|c|c|c|c|c|c|}
\hline \multirow{2}{*}{$\begin{array}{l}\text { Run } \\
\text { No. }\end{array}$} & \multirow{2}{*}{ Variable } & \multicolumn{4}{|c|}{ Concentration } & \multirow{2}{*}{$\begin{array}{l}\text { Temper- } \\
\text { ature }\end{array}$} & \multirow{2}{*}{$\begin{array}{l}\text { Specific } \\
\text { gravity }\end{array}$} \\
\hline & & $\mathrm{NO}_{3}$ & $\mathrm{NO}_{2}$ & $\mathrm{AlO}_{2}$ & $\mathrm{OH}$ & & \\
\hline $\begin{array}{l}\text { BY-7 } \\
\text { BY-7R } \\
\text { BY-07 } \\
\text { BY-8 }\end{array}$ & $\begin{array}{l}\mathrm{NO}_{2} \\
\mathrm{NO}_{2} \\
\mathrm{NO}_{2} \\
\mathrm{NO}_{2} \\
\end{array}$ & $\begin{array}{l}5.65 \\
5.65 \\
5.61 \\
5.67\end{array}$ & $\begin{array}{l}13.03 \\
13.06 \\
13.22 \\
13.27\end{array}$ & $\begin{array}{l}1.955 \\
1.95 \\
2.6 \% \\
1.14\end{array}$ & $\begin{array}{l}5.40 \\
5.40 \\
5.28 \\
5.26\end{array}$ & $\begin{array}{l}80 \\
80 \\
80 \\
80\end{array}$ & $\begin{array}{l}1.565 \\
1.560 \\
1.587 \\
1.572\end{array}$ \\
\hline $\begin{array}{l}B Y-9 A \\
B Y-9 B \\
B Y-10 A \\
B Y-10 B \\
8 Y-11 A \\
B Y-11 B \\
B Y-12 B \\
B Y-12 C \\
B Y-12 D \\
8 Y-13 \\
B Y-14 \\
B Y-15 \\
B Y-16\end{array}$ & $\begin{array}{l}\mathrm{A} 10_{2} \\
\mathrm{~A} 10_{2} \\
\mathrm{~A} 10_{2} \\
\mathrm{~A} 10_{2} \\
\mathrm{~A} 10_{2} \\
\mathrm{~A} 10_{2} \\
\mathrm{~A} 10_{2} \\
\mathrm{~A} 10_{2} \\
\mathrm{~A} 10_{2} \\
\mathrm{~A} 10_{2} \\
\mathrm{~A} 10_{2} \\
\mathrm{~A} 10_{2} \\
\mathrm{~A} 10_{2}\end{array}$ & $\begin{array}{l}9.36 \\
9.36 \\
9.36 \\
9.36 \\
5.62 \\
5.62 \\
5.62 \\
5.62 \\
5.62 \\
9.36 \\
9.36 \\
5.62 \\
5.62\end{array}$ & $\begin{array}{r}12.30 \\
12.30 \\
8.35 \\
8.35 \\
12.30 \\
12.30 \\
8.35 \\
8.35 \\
8.35 \\
12.30 \\
8.35 \\
12.30 \\
8.35\end{array}$ & $\begin{array}{l}3.74 \\
3.6 \% \\
4.03 \\
3.88 \\
3.91 \\
3.82 \\
3.94 \\
4.32 \\
4.28 \\
3.77 \\
4.20 \\
4.23 \\
4.58\end{array}$ & $\begin{array}{l}5.26 \\
5.26 \\
5.26 \\
5.26 \\
5.26 \\
5.26 \\
5.26 \\
5.26 \\
5.26 \\
5.26 \\
5.26 \\
5.26 \\
5.26\end{array}$ & $\begin{array}{l}80 \\
80 \\
80 \\
80 \\
80 \\
80 \\
80 \\
80 \\
80 \\
80 \\
80 \\
80 \\
80\end{array}$ & $\begin{array}{l}1.62 \\
1.62 \\
1.58 \\
1.59 \\
1.60 \\
1.58 \\
1.53 \\
1.55 \\
1.55 \\
1.61 \\
1.59 \\
1.58 \\
1.55\end{array}$ \\
\hline $\begin{array}{l}B Z-1 \\
B Z-1 R \\
B Z-2 \\
B Z-3 \\
B Z-4\end{array}$ & $\begin{array}{l}\mathrm{NO}_{3} \\
\mathrm{NO}_{3} \\
\mathrm{NO}_{3} \\
\mathrm{NO}_{3} \\
\mathrm{NO}_{3}\end{array}$ & $\begin{array}{l}7.88 \\
7.86 \\
7.87 \\
7.39 \\
7.45\end{array}$ & $\begin{array}{l}8.21 \\
8.21 \\
9.01 \\
5.07 \\
5.56\end{array}$ & $\begin{array}{l}1.92 \\
1.92 \\
1.14 \\
1.92 \\
1.14\end{array}$ & $\begin{array}{l}11.30 \\
11.30 \\
11.25 \\
11.30 \\
11.25\end{array}$ & $\begin{array}{l}80 \\
80 \\
80 \\
80 \\
80\end{array}$ & $\begin{array}{l}1.614 \\
1.595 \\
1.596 \\
1.572 \\
1.549\end{array}$ \\
\hline $\begin{array}{l}B Z-5 \\
B Z-5 R \\
B Z-6 \\
B Z-6 R \\
B Z-7 \\
B Z-8\end{array}$ & $\begin{array}{l}\mathrm{NO}_{2} \\
\mathrm{NO}_{2} \\
\mathrm{NO}_{2} \\
\mathrm{NO}_{2} \\
\mathrm{NO}_{2} \\
\mathrm{NO}_{2}\end{array}$ & $\begin{array}{l}6.67 \\
6.67 \\
7.31 \\
7.31 \\
4.12 \\
4.52\end{array}$ & $\begin{array}{r}10.32 \\
10.35 \\
10.42 \\
10.49 \\
9.86 \\
9.94\end{array}$ & $\begin{array}{l}1.92 \\
1.92 \\
1.14 \\
1.14 \\
1.92 \\
1.14\end{array}$ & $\begin{array}{l}11.30 \\
11.30 \\
11.25 \\
11.25 \\
11.30 \\
11.25\end{array}$ & $\begin{array}{l}80 \\
80 \\
80 \\
80 \\
80 \\
80\end{array}$ & $\begin{array}{l}1.598 \\
1.621 \\
1.613 \\
1.607 \\
1.572 \\
1.552\end{array}$ \\
\hline $\begin{array}{l}B Z-9 A \\
B Z-9 B \\
B Z-9 C \\
B Z-10 A \\
B Z-10 B \\
B Z-11 A \\
B Z-11 B \\
B Z-12 A \\
B Z-12 B\end{array}$ & $\begin{array}{l}\mathrm{A} 10_{2} \\
\mathrm{~A} 10_{2} \\
\mathrm{~A} 10_{2} \\
\mathrm{~A} 10_{2} \\
\mathrm{~A} 10_{2} \\
\mathrm{~A} 10_{2} \\
\mathrm{~A} 10_{2} \\
\mathrm{~A} 10_{2} \\
\mathrm{~A} 10_{2}\end{array}$ & $\begin{array}{l}7.00 \\
7.00 \\
7.00 \\
7.00 \\
7.00 \\
4.30 \\
4.30 \\
4.30 \\
4.30\end{array}$ & $\begin{array}{l}8.60 \\
8.60 \\
8.60 \\
5.30 \\
5.30 \\
8.60 \\
8.60 \\
5.30 \\
5.30\end{array}$ & $\begin{array}{l}2.26 \\
2.29 \\
2.43 \\
2.46 \\
2.5 \% \\
2.4 \% \\
2.3 \% \\
2.4 \% \\
2.4 \%\end{array}$ & $\begin{array}{l}11.28 \\
11.28 \\
11.28 \\
11.28 \\
11.28 \\
11.28 \\
11.28 \\
11.28 \\
11.28\end{array}$ & $\begin{array}{l}80 \\
80 \\
80 \\
80 \\
80 \\
80 \\
80 \\
80 \\
80\end{array}$ & $\begin{array}{l}1.57 \\
1.58 \\
1.57 \\
1.55 \\
1.55 \\
1.55 \\
1.55 \\
1.52 \\
1.52\end{array}$ \\
\hline
\end{tabular}


RHO-RE-ST-14 P

Sheet 6 of 7

\begin{tabular}{|c|c|c|c|c|c|c|c|}
\hline \multirow{2}{*}{$\begin{array}{l}\text { Run } \\
\text { No. }\end{array}$} & \multirow{2}{*}{ Variable } & \multicolumn{4}{|c|}{ Concentration } & \multirow{2}{*}{$\begin{array}{l}\text { Temper- } \\
\text { ature }\end{array}$} & \multirow{2}{*}{$\begin{array}{l}\text { Specific } \\
\text { gravity }\end{array}$} \\
\hline & & $\mathrm{NO}_{3}$ & $\mathrm{NO}_{2}$ & $\mathrm{AlO}_{2}$ & $\mathrm{OH}$ & & \\
\hline $\begin{array}{l}C X-1 \\
C X-1 R \\
C X-2 \\
C X-3 \\
C X-4 \\
C X-4 R\end{array}$ & $\begin{array}{l}\mathrm{NO}_{3} \\
\mathrm{NO}_{3} \\
\mathrm{NO}_{3} \\
\mathrm{NO}_{3} \\
\mathrm{NO}_{3} \\
\mathrm{NO}_{3}\end{array}$ & $\begin{array}{l}12.55 \\
12.56 \\
12.55 \\
11.96 \\
11.97 \\
12.01\end{array}$ & $\begin{array}{r}12.50 \\
12.50 \\
12.50 \\
7.47 \\
7.47 \\
7.47\end{array}$ & $\begin{array}{l}1.94 \\
1.94 \\
1.17 \\
1.94 \\
1.17 \\
1.17\end{array}$ & $\begin{array}{l}8.89 \\
8.89 \\
8.90 \\
8.89 \\
8.90 \\
8.90\end{array}$ & $\begin{array}{l}100 \\
100 \\
100 \\
100 \\
100 \\
100\end{array}$ & $\begin{array}{l}1.662 \\
1.652 \\
1.624 \\
1.606 \\
1.601 \\
1.604\end{array}$ \\
\hline $\begin{array}{l}C X-5 \\
C X-5 R \\
C X-6 \\
C X-6 R \\
C X-7 \\
C X-8\end{array}$ & $\begin{array}{l}\mathrm{NO}_{2} \\
\mathrm{NO}_{2} \\
\mathrm{NO}_{2} \\
\mathrm{NO}_{2} \\
\mathrm{NO}_{2} \\
\mathrm{NO}_{2}\end{array}$ & $\begin{array}{r}10.50 \\
10.50 \\
10.50 \\
10.50 \\
5.58 \\
5.58\end{array}$ & $\begin{array}{l}16.67 \\
16.67 \\
16.70 \\
16.69 \\
15.77 \\
15.79\end{array}$ & $\begin{array}{l}1.94 \\
1.94 \\
1.17 \\
1.17 \\
1.94 \\
1.17\end{array}$ & $\begin{array}{l}8.89 \\
8.89 \\
8.90 \\
8.90 \\
8.89 \\
8.90\end{array}$ & $\begin{array}{l}100 \\
100 \\
100 \\
100 \\
100 \\
100\end{array}$ & $\begin{array}{l}1.666 \\
1.640 \\
1.635 \\
1.663 \\
1.588 \\
1.590\end{array}$ \\
\hline $\begin{array}{l}C X-9 A \\
C X-9 B \\
C X-10 B \\
C X-10 C \\
C X-11 B \\
C X-11 C \\
C X-12 A \\
C X-12 B \\
C X-12 C\end{array}$ & $\begin{array}{l}A 1 O_{2} \\
A 10_{2} \\
A 1 O_{2} \\
A 10_{2} \\
A 10_{2} \\
A 10_{2} \\
A 10_{2} \\
A 10_{2} \\
A 10_{2}\end{array}$ & $\begin{array}{r}10.50 \\
10.50 \\
10.50 \\
10.50 \\
5.58 \\
5.58 \\
5.58 \\
5.58 \\
5.58\end{array}$ & $\begin{array}{r}12.50 \\
12.50 \\
7.47 \\
7.47 \\
12.50 \\
12.50 \\
7.47 \\
7.47 \\
7.47\end{array}$ & $\begin{array}{l}3.64 \\
3.82 \\
4.14 \\
3.55 \\
4.59 \\
3.68 \\
4.24 \\
4.12 \\
4.03\end{array}$ & $\begin{array}{l}8.85 \\
8.85 \\
8.85 \\
8.85 \\
8.85 \\
8.85 \\
8.85 \\
8.85 \\
8.85\end{array}$ & $\begin{array}{l}100 \\
100 \\
100 \\
100 \\
100 \\
100 \\
100 \\
100 \\
100\end{array}$ & $\begin{array}{l}1.66 \\
1.66 \\
1.61 \\
1.60 \\
1.60 \\
1.58 \\
1.55 \\
1.55 \\
1.56\end{array}$ \\
\hline $\begin{array}{l}C Y-1 \\
C Y-1 R \\
C Y-01 \\
C Y-2 \\
C Y-2 R \\
C Y-3 \\
C Y-03 \\
C Y-4\end{array}$ & $\begin{array}{l}\mathrm{NO}_{3} \\
\mathrm{NO}_{3} \\
\mathrm{NO}_{3} \\
\mathrm{NO}_{3} \\
\mathrm{NO}_{3} \\
\mathrm{NO}_{3} \\
\mathrm{NO}_{3} \\
\mathrm{NO}_{3}\end{array}$ & $\begin{array}{l}14.07 \\
14.07 \\
14.20 \\
14.09 \\
14.07 \\
13.70 \\
13.75 \\
13.73\end{array}$ & $\begin{array}{r}14.46 \\
14.46 \\
14.48 \\
14.50 \\
14.46 \\
8.36 \\
8.38 \\
8.36\end{array}$ & $\begin{array}{l}1.97 \\
1.997 \\
2.68 \\
1.14 \\
1.15 \\
1.97 \\
2.68 \\
1.15\end{array}$ & $\begin{array}{l}5.28 \\
5.28 \\
5.31 \\
5.26 \\
5.15 \\
5.28 \\
5.31 \\
5.15\end{array}$ & $\begin{array}{l}100 \\
100 \\
100 \\
100 \\
100 \\
100 \\
100 \\
100\end{array}$ & $\begin{array}{l}1.712 \\
1.667 \\
1.669 \\
1.680 \\
1.667 \\
1.609 \\
1.613 \\
1.602\end{array}$ \\
\hline $\begin{array}{l}C Y-5 \\
C Y-5 R \\
C Y-05 \\
C Y-6 \\
C Y-6 R \\
C Y-7 \\
C Y-07 \\
C Y-8 \\
C Y-8 R\end{array}$ & $\begin{array}{l}\mathrm{NO}_{2} \\
\mathrm{NO}_{2} \\
\mathrm{NO}_{2} \\
\mathrm{NO}_{2} \\
\mathrm{NO}_{2} \\
\mathrm{NO}_{2} \\
\mathrm{NO}_{2} \\
\mathrm{NO}_{2} \\
\mathrm{NO}_{2}\end{array}$ & $\begin{array}{r}11.76 \\
11.76 \\
11.78 \\
11.77 \\
11.77 \\
5.65 \\
5.66 \\
5.65 \\
5.65\end{array}$ & $\begin{array}{l}18.77 \\
18.69 \\
18.90 \\
18.82 \\
18.76 \\
18.01 \\
18.04 \\
18.11 \\
18.08\end{array}$ & $\begin{array}{l}1.97 \\
1.97 \\
2.68 \\
1.15 \\
1.15 \\
1.97 \\
2.68 \\
1.15 \\
1.15\end{array}$ & $\begin{array}{l}5.28 \\
5.28 \\
5.31 \\
5.15 \\
5.15 \\
5.28 \\
5.28 \\
5.15 \\
5.15\end{array}$ & $\begin{array}{l}100 \\
100 \\
100 \\
100 \\
100 \\
100 \\
100 \\
100 \\
100\end{array}$ & $\begin{array}{l}1.728 \\
1.668 \\
1.672 \\
1.681 \\
1.680 \\
1.615 \\
1.638 \\
1.593 \\
1.575\end{array}$ \\
\hline
\end{tabular}


RHO-RE-ST-14 P

Sheet 7 of $i$

\begin{tabular}{|c|c|c|c|c|c|c|c|}
\hline \multirow{2}{*}{$\begin{array}{l}\text { Run } \\
\text { No. }\end{array}$} & \multirow{2}{*}{ Variable } & \multicolumn{4}{|c|}{ Concentration } & \multirow{2}{*}{$\begin{array}{l}\text { Temper- } \\
\text { ature }\end{array}$} & \multirow{2}{*}{$\begin{array}{l}\text { Specific } \\
\text { gravity }\end{array}$} \\
\hline & & $\mathrm{NO}_{3}$ & $\mathrm{NO}_{2}$ & $\mathrm{AlO}_{2}$ & $\mathrm{OH}$ & & \\
\hline $\begin{array}{l}C Y-9 B \\
C Y-9 C \\
C Y-10 B \\
C Y-10 C \\
C Y-10 M \\
C Y-10 N \\
C Y-11 B \\
C Y-11 C \\
C Y-12 B \\
C Y-12 C\end{array}$ & $\begin{array}{l}A 10_{2} \\
A 10_{2} \\
A 10_{2} \\
A 10_{2} \\
A 10_{2} \\
A 10_{2} \\
A 10_{2} \\
A 10_{2} \\
A 10_{2} \\
A 10_{2}\end{array}$ & $\begin{array}{r}11.80 \\
11.80 \\
11.80 \\
11.80 \\
11.80 \\
11.80 \\
5.67 \\
5.67 \\
5.67 \\
5.67\end{array}$ & $\begin{array}{r}14.50 \\
14.50 \\
8.39 \\
8.39 \\
11.40 \\
11.40 \\
14.50 \\
14.50 \\
8.39 \\
8.39\end{array}$ & $\begin{array}{l}4.03 \\
4.57 \\
4.43 \\
5.45 \\
4.73 \\
4.86 \\
4.82 \\
4.74 \\
4.79 \\
4.82\end{array}$ & $\begin{array}{l}5.26 \\
5.26 \\
5.26 \\
5.26 \\
5.26 \\
5.26 \\
5.26 \\
5.26 \\
5.26 \\
5.26\end{array}$ & $\begin{array}{l}100 \\
100 \\
100 \\
100 \\
100 \\
100 \\
100 \\
100 \\
100 \\
100\end{array}$ & $\begin{array}{l}1.67 \\
1.65 \\
1.61 \\
1.64 \\
1.64 \\
1.65 \\
1.62 \\
1.61 \\
1.55 \\
1.56\end{array}$ \\
\hline $\begin{array}{l}C Z-1 \\
C Z-1 R \\
C Z-2 \\
C Z-2 R \\
C Z-3 \\
C Z-4\end{array}$ & $\begin{array}{l}\mathrm{NO}_{3} \\
\mathrm{NO}_{3} \\
\mathrm{NO} 3 \\
\mathrm{NO}_{3} \\
\mathrm{NO}_{3} \\
\mathrm{NO}_{3}\end{array}$ & $\begin{array}{l}12.26 \\
12.28 \\
12.09 \\
12.09 \\
11.46 \\
11.36\end{array}$ & $\begin{array}{r}12.61 \\
12.61 \\
12.61 \\
12.61 \\
7.51 \\
7.51\end{array}$ & $\begin{array}{l}1.89 \\
1.89 \\
1.15 \\
1.15 \\
1.89 \\
1.15\end{array}$ & $\begin{array}{l}11.15 \\
11.15 \\
11.12 \\
11.12 \\
11.15 \\
11.12\end{array}$ & $\begin{array}{l}100 \\
100 \\
100 \\
100 \\
100 \\
100\end{array}$ & $\begin{array}{l}1.650 \\
1.651 \\
1.649 \\
1.653 \\
1.601 \\
1.615\end{array}$ \\
\hline $\begin{array}{l}C Z-5 \\
C Z-5 R \\
C Z-6 \\
C Z-6 R \\
C Z-7 \\
C Z-8\end{array}$ & $\begin{array}{l}\mathrm{NO}_{2} \\
\mathrm{NO}_{2} \\
\mathrm{NO} 2 \\
\mathrm{NO} 2 \\
\mathrm{NO}_{2} \\
\mathrm{NO} 2\end{array}$ & $\begin{array}{l}9.38 \\
9.38 \\
9.38 \\
9.38 \\
5.85 \\
5.85\end{array}$ & $\begin{array}{l}15.89 \\
15.89 \\
15.86 \\
15.86 \\
15.14 \\
15.11\end{array}$ & $\begin{array}{l}1.89 \\
1.89 \\
1.15 \\
1.15 \\
1.89 \\
1.15\end{array}$ & $\begin{array}{l}11.15 \\
11.15 \\
11.12 \\
11.12 \\
11.15 \\
11.12\end{array}$ & $\begin{array}{l}100 \\
100 \\
100 \\
100 \\
100 \\
100\end{array}$ & $\begin{array}{l}1.712 \\
1.649 \\
1.671 \\
1.638 \\
1.606 \\
1.603\end{array}$ \\
\hline $\begin{array}{l}C Z-9 A \\
C Z-9 B \\
C Z-9 C \\
C Z-10 A \\
C Z-10 B \\
C Z-11 A \\
C Z-11 B \\
C Z-12 A \\
C Z-12 B\end{array}$ & $\begin{array}{l}A 10_{2} \\
A 10_{2} \\
A 10_{2} \\
A 10_{2} \\
A 10_{2} \\
A 10_{2} \\
A 10_{2} \\
A 10_{2} \\
A 10_{2}\end{array}$ & $\begin{array}{l}9.38 \\
9.38 \\
9.38 \\
9.38 \\
9.38 \\
5.85 \\
5.85 \\
5.85 \\
5.85\end{array}$ & $\begin{array}{r}12.61 \\
12.61 \\
12.61 \\
7.51 \\
7.51 \\
12.61 \\
12.61 \\
7.51 \\
7.51\end{array}$ & $\begin{array}{l}2.87 \\
2.98 \\
2.95 \\
3.30 \\
3.33 \\
3.56 \\
3.58 \\
3.02 \\
3.13\end{array}$ & $\begin{array}{l}11.25 \\
11.25 \\
11.25 \\
11.25 \\
11.25 \\
11.25 \\
11.25 \\
11.25 \\
11.25\end{array}$ & $\begin{array}{l}100 \\
100 \\
100 \\
100 \\
100 \\
100 \\
100 \\
100 \\
100\end{array}$ & $\begin{array}{l}1.63 \\
1.64 \\
1.64 \\
1.60 \\
1.60 \\
1.61 \\
1.61 \\
1.56 \\
1.57\end{array}$ \\
\hline
\end{tabular}

NOTE: Explanation of sample numbers:

$R, S=$ Re-runs of main sample (no suffix)

$P, Q, T=\mathrm{No}_{3}$ or $\mathrm{SO}_{4}$

$E, F, G=$ No complexants

$\mathrm{M}, \mathrm{N}=$ Additional level of $\mathrm{NO}_{3}$ or $\mathrm{NO}_{2}$, with or without $\mathrm{CO}_{3}$

$01,03,05,07=$ Third leve 1 of $\mathrm{AlO}_{2}$ 
RHO-RE-ST-14.P

APPENDIX B

PHASE DIAGRAM, COMPLETE; CONCENTIRATIONS IN MOLARITIES

Sheet 1 of 7

\begin{tabular}{|c|c|c|c|c|c|c|c|}
\hline \multirow{2}{*}{$\begin{array}{l}\text { Run } \\
\text { No. }\end{array}$} & \multirow{2}{*}{ Variable } & \multicolumn{4}{|c|}{ Concentration } & \multirow{2}{*}{$\begin{array}{l}\text { Temper- } \\
\text { ature }\end{array}$} & \multirow{2}{*}{$\begin{array}{l}\text { Specific } \\
\text { gravity } \\
\text {.. }\end{array}$} \\
\hline & & $\mathrm{NO}_{3}$ & $\mathrm{NO}_{2}$ & $\mathrm{AlO}_{2}$ & $\mathrm{OH}$ & & \\
\hline $\begin{array}{l}A X-1 \\
A X-1 R \\
A X-1 P \\
A X-1 Q \\
A X-2 \\
A X-2 R \\
A X-2 S \\
A X-3 \\
A X-3 R \\
A X-4 \\
A X-4 R \\
A X-4 P \\
A X-4 Q\end{array}$ & $\begin{array}{l}\mathrm{NO}_{3} \\
\mathrm{NO}_{3} \\
\mathrm{NO}_{3} \\
\mathrm{NO}_{3} \\
\mathrm{NO}_{3} \\
\mathrm{NO}_{3} \\
\mathrm{NO}_{3} \\
\mathrm{NO}_{3} \\
\mathrm{NO}_{3} \\
\mathrm{NO}_{3} \\
\mathrm{NO}_{3} \\
\mathrm{NO}_{3} \\
\mathrm{NO}_{3}\end{array}$ & $\begin{array}{l}3.47 \\
3.51 \\
3.40 \\
3.41 \\
3.60 \\
3.60 \\
3.53 \\
3.51 \\
3.58 \\
3.72 \\
3.66 \\
3.64 \\
3.62\end{array}$ & $\begin{array}{l}4.37 \\
4.43 \\
4.34 \\
4.35 \\
4.53 \\
4.43 \\
4.42 \\
3.06 \\
3.09 \\
3.18 \\
3.14 \\
3.13 \\
3.13\end{array}$ & $\begin{array}{l}1.18 \\
1.20 \\
1.14 \\
1.15 \\
0.74 \\
0.72 \\
0.72 \\
1.24 \\
1.25 \\
0.78 \\
0.77 \\
0.75 \\
0.75\end{array}$ & $\begin{array}{l}5.23 \\
5.30 \\
5.24 \\
5.25 \\
5.48 \\
5.35 \\
5.34 \\
5.50 \\
5.55 \\
5.76 \\
5.68 \\
5.69 \\
5.68\end{array}$ & $\begin{array}{l}60 \\
60 \\
60 \\
60 \\
60 \\
60 \\
60 \\
60 \\
60 \\
60 \\
60 \\
60 \\
60\end{array}$ & $\begin{array}{l}1.574 \\
1.596 \\
1.554 \\
1.558 \\
1.578 \\
1.547 \\
1.541 \\
1.539 \\
1.556 \\
1.543 \\
1.522 \\
1.513 \\
1.508\end{array}$ \\
\hline $\begin{array}{l}A X-5 \\
A X-5 R \\
A X-5 P \\
A X-5 Q \\
A X-6 \\
A X-6 R \\
A X-7 \\
A X-7 R \\
A X-8 \\
A X-8 R \\
A X-8 P\end{array}$ & $\begin{array}{l}\mathrm{NO}_{2} \\
\mathrm{NO}_{2} \\
\mathrm{NO}_{2} \\
\mathrm{NO}_{2} \\
\mathrm{NO}_{2} \\
\mathrm{NO}_{2} \\
\mathrm{NO}_{2} \\
\mathrm{NO}_{2} \\
\mathrm{NO}_{2} \\
\mathrm{NO}_{2} \\
\mathrm{NO}_{2}\end{array}$ & $\begin{array}{l}3.27 \\
3.22 \\
3.23 \\
3.22 \\
3.37 \\
3.32 \\
2.17 \\
2.12 \\
2.19 \\
2.25 \\
2.18\end{array}$ & $\begin{array}{l}4.65 \\
4.61 \\
4.60 \\
4.59 \\
4.94 \\
4.82 \\
4.90 \\
4.80 \\
5.03 \\
5.18 \\
4.90\end{array}$ & $\begin{array}{l}1.19 \\
1.17 \\
1.14 \\
1.14 \\
0.74 \\
0.73 \\
1.26 \\
1.23 \\
0.76 \\
0.79 \\
0.75\end{array}$ & $\begin{array}{l}5.26 \\
5.18 \\
5.24 \\
5.22 \\
5.47 \\
5.38 \\
5.58 \\
5.45 \\
5.67 \\
5.84 \\
5.68\end{array}$ & $\begin{array}{l}60 \\
60 \\
60 \\
60 \\
60 \\
60 \\
60 \\
60 \\
60 \\
60 \\
60\end{array}$ & $\begin{array}{l}1.584 \\
1.561 \\
1.557 \\
1.553 \\
1.586 \\
1.556 \\
1.567 \\
1.532 \\
1.526 \\
1.572 \\
1.509\end{array}$ \\
\hline $\begin{array}{l}A X-9 A \\
A X-9 B \\
A X-10 A \\
A X-10 B \\
A X-11 A \\
A X-11 B \\
A X-12 A \\
A X-12 B \\
A X-13 \\
A X-14 \\
A X-15 \\
A X-16\end{array}$ & $\begin{array}{l}A 10_{2} \\
A 10_{2} \\
A 102 \\
A 10_{2} \\
A 10_{2} \\
A 10_{2} \\
A 10_{2} \\
A 10_{2} \\
A 10_{2} \\
A 10_{2} \\
A 10_{2} \\
A 10_{2}\end{array}$ & $\begin{array}{l}2.80 \\
2.67 \\
2.87 \\
2.87 \\
1.79 \\
1.79 \\
1.88 \\
1.88 \\
2.86 \\
2.84 \\
1.82 \\
1.92\end{array}$ & $\begin{array}{l}3.76 \\
3.59 \\
2.58 \\
2.58 \\
3.84 \\
3.84 \\
2.69 \\
2.69 \\
3.84 \\
2.55 \\
3.90 \\
2.74\end{array}$ & $\begin{array}{l}1.29 \\
1.24 \\
1.37 \\
1.34 \\
1.41 \\
1.28 \\
1.43 \\
1.50 \\
1.25 \\
1.31 \\
1.30 \\
1.49\end{array}$ & $\begin{array}{l}4.52 \\
4.32 \\
4.64 \\
4.64 \\
4.62 \\
4.62 \\
4.84 \\
4.84 \\
4.61 \\
4.59 \\
4.69 \\
4.95\end{array}$ & $\begin{array}{l}60 \\
60 \\
60 \\
60 \\
60 \\
60 \\
60 \\
60 \\
60 \\
60 \\
60 \\
60\end{array}$ & $\begin{array}{l}1.54 \\
1.54 \\
1.53 \\
1.53 \\
1.52 \\
1.52 \\
1.50 \\
1.50 \\
1.55 \\
1.53 \\
1.52 \\
1.51\end{array}$ \\
\hline
\end{tabular}


RHO-RE-ST-14 P

Sheet 2 of 7

\begin{tabular}{|c|c|c|c|c|c|c|c|}
\hline \multirow{2}{*}{$\begin{array}{l}\text { Run } \\
\text { No. }\end{array}$} & \multirow{2}{*}{ Variable } & \multicolumn{4}{|c|}{ Concentration } & \multirow{2}{*}{$\begin{array}{l}\text { Temper- } \\
\text { ature }\end{array}$} & \multirow{2}{*}{$\begin{array}{l}\text { Specific } \\
\text { gravity }\end{array}$} \\
\hline & & $\mathrm{NO}_{3}$ & $\mathrm{NO}_{2}$ & $\mathrm{AlO}_{2}$ & $\mathrm{OH}$ & & \\
\hline $\begin{array}{l}A Y-1 \\
A Y-1 R \\
A Y-1 E \\
A Y-1 F \\
A Y-01 \\
A Y-2 \\
A Y-3 \\
A Y-3 R \\
A Y-3 E \\
A Y-03 \\
A Y-3 M \\
A Y-4 \\
A Y-4 R \\
A Y-4 M \\
A Y-4 N\end{array}$ & $\begin{array}{l}\mathrm{NO}_{3} \\
\mathrm{NO}_{3} \\
\mathrm{NO}_{3} \\
\mathrm{NO} \\
\mathrm{NO} \\
\mathrm{NO}_{3} \\
\mathrm{NO}_{3} \\
\mathrm{NO}_{3} \\
\mathrm{NO}_{3} \\
\mathrm{NO}_{3} \\
\mathrm{NO}_{3} \\
\mathrm{NO}_{3} \\
\mathrm{NO}_{3} \\
\mathrm{NO}_{3} \\
\mathrm{NO}_{3} \\
\mathrm{NO}_{3}\end{array}$ & $\begin{array}{l}3.96 \\
3.93 \\
4.02 \\
3.99 \\
3.86 \\
4.17 \\
4.33 \\
4.35 \\
4.42 \\
4.21 \\
4.08 \\
4.67 \\
4.65 \\
4.33 \\
4.30\end{array}$ & $\begin{array}{l}5.22 \\
5.23 \\
5.27 \\
5.23 \\
5.07 \\
5.43 \\
3.10 \\
3.13 \\
3.11 \\
3.00 \\
4.58 \\
3.20 \\
3.13 \\
4.77 \\
4.75\end{array}$ & $\begin{array}{l}1.10 \\
1.10 \\
1.14 \\
1.13 \\
1.48 \\
0.67 \\
1.20 \\
1.21 \\
1.24 \\
1.62 \\
1.13 \\
0.73 \\
0.72 \\
0.69 \\
0.68\end{array}$ & $\begin{array}{l}3.01 \\
3.02 \\
3.19 \\
3.16 \\
2.94 \\
3.10 \\
3.30 \\
3.33 \\
3.46 \\
3.21 \\
3.10 \\
3.37 \\
3.33 \\
3.20 \\
3.14\end{array}$ & $\begin{array}{l}60 \\
60 \\
60 \\
60 \\
60 \\
60 \\
60 \\
60 \\
60 \\
60 \\
60 \\
60 \\
60 \\
60 \\
60\end{array}$ & $\begin{array}{l}1.554 \\
1.554 \\
1.558 \\
1.546 \\
1.559 \\
1.551 \\
1.520 \\
1.534 \\
1.515 \\
1.526 \\
1.544 \\
1.514 \\
1.501 \\
1.546 \\
1.531\end{array}$ \\
\hline $\begin{array}{l}A Y-5 \\
A Y-5 R \\
A Y-5 E \\
A Y-5 F \\
A Y-56 \\
A Y-05 \\
A Y-6 \\
A Y-6 R \\
A Y-7 \\
A Y-07 \\
A Y-8 \\
A Y-8 R \\
A Y-8 E\end{array}$ & $\begin{array}{l}\mathrm{NO}_{2} \\
\mathrm{NO}_{2} \\
\mathrm{NO}_{2} \\
\mathrm{NO}_{2} \\
\mathrm{NO}_{2} \\
\mathrm{NO}_{2} \\
\mathrm{NO} 2 \\
\mathrm{NO} 2 \\
\mathrm{NO} \\
\mathrm{NO} \\
\mathrm{NO}_{2} \\
\mathrm{NO}_{2} \\
\mathrm{NO}_{2}\end{array}$ & $\begin{array}{l}3.69 \\
3.66 \\
3.66 \\
3.66 \\
3.65 \\
3.53 \\
3.74 \\
3.77 \\
2.45 \\
2.36 \\
2.49 \\
2.48 \\
2.53\end{array}$ & $\begin{array}{l}5.59 \\
5.53 \\
5.57 \\
5.55 \\
5.53 \\
5.37 \\
5.78 \\
5.83 \\
5.90 \\
5.67 \\
6.18 \\
6.11 \\
6.23\end{array}$ & $\begin{array}{l}1.12 \\
1.11 \\
1.15 \\
1.14 \\
1.14 \\
1.49 \\
0.67 \\
0.67 \\
1.18 \\
1.58 \\
0.71 \\
0.70 \\
0.74\end{array}$ & $\begin{array}{l}3.08 \\
3.05 \\
3.19 \\
3.19 \\
3.19 \\
2.96 \\
3.08 \\
3.11 \\
3.25 \\
3.14 \\
3.26 \\
3.25 \\
3.43\end{array}$ & $\begin{array}{l}60 \\
60 \\
60 \\
60 \\
60 \\
60 \\
60 \\
60 \\
60 \\
60 \\
60 \\
60 \\
60\end{array}$ & $\begin{array}{l}1.575 \\
1.559 \\
1.549 \\
1.547 \\
1.543 \\
1.558 \\
1.535 \\
1.548 \\
1.540 \\
1.531 \\
1.506 \\
1.495 \\
1.518\end{array}$ \\
\hline $\begin{array}{l}A Y-9 B \\
A Y-9 D \\
A Y-9 E \\
A Y-10 B \\
A Y-10 C \\
A Y-10 D \\
A Y-11 B \\
A Y-11 D \\
A Y-12 B \\
A Y-12 D \\
A Y-12 E\end{array}$ & $\begin{array}{l}A 10_{2} \\
A 10_{2} \\
A 10_{2} \\
A 10_{2} \\
A 10_{2} \\
A 10_{2} \\
A 10_{2} \\
A 10_{2} \\
A 10_{2} \\
A 10_{2} \\
A 10_{2}\end{array}$ & $\begin{array}{l}2.95 \\
3.03 \\
3.03 \\
3.20 \\
3.22 \\
3.20 \\
1.97 \\
1.98 \\
2.16 \\
1.95 \\
1.97\end{array}$ & $\begin{array}{l}4.27 \\
4.38 \\
4.38 \\
2.51 \\
2.52 \\
2.51 \\
4.52 \\
4.55 \\
2.68 \\
2.42 \\
2.45\end{array}$ & $\begin{array}{l}2.09 \\
1.82 \\
1.89 \\
2.02 \\
2.00 \\
1.96 \\
1.96 \\
2.19 \\
3.00 \\
2.18 \\
2.34\end{array}$ & $\begin{array}{l}2.46 \\
2.53 \\
2.53 \\
2.67 \\
2.68 \\
2.67 \\
2.61 \\
2.62 \\
2.85 \\
2.56 \\
2.61\end{array}$ & $\begin{array}{l}60 \\
60 \\
60 \\
60 \\
60 \\
60 \\
60 \\
60 \\
60 \\
60 \\
60\end{array}$ & $\begin{array}{l}1.53 \\
1.57 \\
1.57 \\
1.54 \\
1.55 \\
1.54 \\
1.55 \\
1.56 \\
1.54 \\
1.49 \\
1.51\end{array}$ \\
\hline $\begin{array}{l}A Z-1 \\
A Z-1 R \\
A Z-1 S \\
A Z-2\end{array}$ & $\begin{array}{l}\mathrm{NO}_{3} \\
\mathrm{NO}_{3} \\
\mathrm{NO}_{3} \\
\mathrm{NO}_{3}\end{array}$ & $\begin{array}{l}3.06 \\
3.07 \\
3.12 \\
3.16\end{array}$ & $\begin{array}{l}3.25 \\
3.27 \\
3.24 \\
3.63\end{array}$ & $\begin{array}{l}1.18 \\
1.18 \\
1.16 \\
0.71\end{array}$ & $\begin{array}{l}6.93 \\
6.95 \\
6.85 \\
7.00\end{array}$ & $\begin{array}{l}60 \\
60 \\
60 \\
60\end{array}$ & $\begin{array}{l}1.546 \\
1.551 \\
1.546 \\
1.540\end{array}$ \\
\hline
\end{tabular}


RHO-RE-ST-14 P

Sheet 3 of ?

\begin{tabular}{|c|c|c|c|c|c|c|c|}
\hline \multirow{2}{*}{$\begin{array}{l}\text { Run } \\
\text { No. }\end{array}$} & \multirow{2}{*}{ Variable } & \multicolumn{4}{|c|}{ Concentration } & \multirow{2}{*}{$\begin{array}{l}\text { Temper- } \\
\text { ature }\end{array}$} & \multirow{2}{*}{$\begin{array}{l}\text { Specific } \\
\text { gravity }\end{array}$} \\
\hline & & $\mathrm{NO}_{3}$ & $\mathrm{NO}_{2}$ & $\mathrm{~A} \mathrm{O}_{2}$ & $\mathrm{OH}$ & & \\
\hline $\begin{array}{l}A Z-3 \\
A Z-3 R \\
A Z-4\end{array}$ & $\begin{array}{l}\mathrm{NO}_{3} \\
\mathrm{NO}_{3} \\
\mathrm{NO}_{3}\end{array}$ & $\begin{array}{l}3.08 \\
3.16 \\
3.22\end{array}$ & $\begin{array}{l}2.31 \\
2.31 \\
2.59\end{array}$ & $\begin{array}{l}1.23 \\
1.21 \\
0.74\end{array}$ & $\begin{array}{l}7.22 \\
7.14 \\
7.35\end{array}$ & $\begin{array}{l}60 \\
60 \\
60\end{array}$ & $\begin{array}{l}1.527 \\
1.529 \\
1.525\end{array}$ \\
\hline $\begin{array}{l}A Z-5 \\
A Z-5 R \\
A Z-5 S \\
A Z-6 \\
A Z-6 R \\
A Z-7 \\
A Z-7 R \\
A Z-8 \\
A Z-8 R\end{array}$ & $\begin{array}{l}\mathrm{NO}_{2} \\
\mathrm{NO}_{2} \\
\mathrm{NO}_{2} \\
\mathrm{NO}_{2} \\
\mathrm{NO}_{2} \\
\mathrm{NO}_{2} \\
\mathrm{NO}_{2} \\
\mathrm{NO}_{2} \\
\mathrm{NO}_{2}\end{array}$ & $\begin{array}{l}2.61 \\
2.61 \\
2.60 \\
2.91 \\
2.92 \\
1.97 \\
1.95 \\
2.19 \\
2.19\end{array}$ & $\begin{array}{l}4.03 \\
4.05 \\
4.12 \\
4.19 \\
4.17 \\
4.08 \\
4.18 \\
4.26 \\
4.23\end{array}$ & $\begin{array}{l}1.16 \\
1.16 \\
1.15 \\
0.70 \\
0.70 \\
1.20 \\
1.18 \\
0.73 \\
0.73\end{array}$ & $\begin{array}{l}6.86 \\
6.84 \\
6.77 \\
6.92 \\
6.96 \\
7.09 \\
6.98 \\
7.16 \\
7.17\end{array}$ & $\begin{array}{l}60 \\
60 \\
60 \\
60 \\
60 \\
60 \\
60 \\
60 \\
60\end{array}$ & $\begin{array}{l}1.551 \\
1.548 \\
1.550 \\
1.547 \\
1.552 \\
1.534 \\
1.531 \\
1.525 \\
1.525\end{array}$ \\
\hline $\begin{array}{l}A Z-9 A \\
A Z-9 B \\
A Z-10 A \\
A Z-10 B \\
A Z-11 A \\
A Z-11 B \\
A Z-12 A \\
A Z-12 B\end{array}$ & $\begin{array}{l}A 10_{2} \\
A 10_{2} \\
A 10_{2} \\
A 10_{2} \\
A 10_{2} \\
A 10_{2} \\
A 10_{2} \\
A 10_{2}\end{array}$ & $\begin{array}{l}2.41 \\
2.32 \\
2.49 \\
2.38 \\
1.79 \\
1.71 \\
1.84 \\
1.86\end{array}$ & $\begin{array}{l}2.95 \\
2.83 \\
2.07 \\
1.99 \\
3.02 \\
2.90 \\
2.13 \\
2.14\end{array}$ & $\begin{array}{l}1.01 \\
0.92 \\
1.01 \\
0.95 \\
0.99 \\
0.92 \\
1.05 \\
1.19\end{array}$ & $\begin{array}{l}6.05 \\
5.81 \\
6.23 \\
5.98 \\
6.20 \\
5.95 \\
6.40 \\
6.44\end{array}$ & $\begin{array}{l}60 \\
60 \\
60 \\
60 \\
60 \\
60 \\
60 \\
60\end{array}$ & $\begin{array}{l}1.53 \\
1.53 \\
1.51 \\
1.51 \\
1.51 \\
1.51 \\
1.49 \\
1.50\end{array}$ \\
\hline $\begin{array}{l}8 X-1 \\
B X-1 R \\
B X-1 P \\
B X-1 Q \\
B X-1 T \\
B X-2 \\
B X-3 \\
B X-4 \\
B X-4 P \\
B X-4 Q \\
8 X-4 M \\
B X-4 N\end{array}$ & $\begin{array}{l}\mathrm{NO}_{3} \\
\mathrm{NO}_{3} \\
\mathrm{NO}_{3} \\
\mathrm{NO}_{3} \\
\mathrm{NO}_{3} \\
\mathrm{NO}_{3} \\
\mathrm{NO} \\
\mathrm{NO}_{3} \\
\mathrm{NO} \\
\mathrm{NO}_{3} \\
\mathrm{NO}_{3} \\
\mathrm{NO}_{3}\end{array}$ & $\begin{array}{l}4.55 \\
4.55 \\
4.49 \\
4.50 \\
4.48 \\
4.66 \\
4.62 \\
4.76 \\
4.75 \\
4.77 \\
4.92 \\
4.97\end{array}$ & $\begin{array}{l}5.31 \\
5.46 \\
5.29 \\
5.35 \\
5.27 \\
5.47 \\
4.10 \\
4.29 \\
4.18 \\
4.20 \\
2.94 \\
2.93\end{array}$ & $\begin{array}{l}1.03 \\
1.06 \\
1.00 \\
1.01 \\
1.00 \\
0.63 \\
1.09 \\
0.68 \\
0.65 \\
0.66 \\
0.71 \\
0.70\end{array}$ & $\begin{array}{l}4.55 \\
4.69 \\
4.58 \\
4.62 \\
4.59 \\
4.73 \\
4.84 \\
5.10 \\
4.98 \\
5.04 \\
5.31 \\
5.35\end{array}$ & $\begin{array}{l}80 \\
80 \\
80 \\
80 \\
80 \\
80 \\
80 \\
80 \\
80 \\
80 \\
80 \\
80\end{array}$ & $\begin{array}{l}1.604 \\
1.640 \\
1.589 \\
1.602 \\
1.589 \\
1.604 \\
1.580 \\
1.595 \\
1.558 \\
1.571 \\
1.554 \\
1.554\end{array}$ \\
\hline $\begin{array}{l}B X-5 \\
B X-5 R \\
B X-5 S \\
B X-5 P \\
B X-6 \\
B X-6 R \\
B X-6 P \\
B X-6 Q \\
B X-7\end{array}$ & $\begin{array}{l}\mathrm{NO}_{2} \\
\mathrm{NO}_{2} \\
\mathrm{NO}_{2} \\
\mathrm{NO}_{2} \\
\mathrm{NO}_{2} \\
\mathrm{NO}_{2} \\
\mathrm{NO}_{2} \\
\mathrm{NO}_{2} \\
\mathrm{NO} 2\end{array}$ & $\begin{array}{l}4.20 \\
4.18 \\
4.17 \\
4.22 \\
4.28 \\
4.19 \\
4.30 \\
4.30 \\
3.10\end{array}$ & $\begin{array}{l}6.07 \\
5.65 \\
5.83 \\
5.98 \\
6.09 \\
6.05 \\
6.07 \\
6.02 \\
6.15\end{array}$ & $\begin{array}{l}1.02 \\
1.02 \\
1.03 \\
1.01 \\
0.62 \\
0.61 \\
0.62 \\
0.62 \\
1.10\end{array}$ & $\begin{array}{l}4.53 \\
4.50 \\
4.56 \\
4.62 \\
4.65 \\
4.55 \\
4.69 \\
4.68 \\
4.89\end{array}$ & $\begin{array}{l}80 \\
80 \\
80 \\
80 \\
80 \\
80 \\
80 \\
80 \\
80\end{array}$ & $\begin{array}{l}1.622 \\
1.586 \\
1.615 \\
1.621 \\
1.600 \\
1.572 \\
1.599 \\
1.595 \\
1.602\end{array}$ \\
\hline
\end{tabular}


RHO-RE-ST-14 P

Sheet 4 of 7

\begin{tabular}{|c|c|c|c|c|c|c|c|}
\hline \multirow{2}{*}{$\begin{array}{l}\text { Run } \\
\text { No. }\end{array}$} & \multirow{2}{*}{ Variable } & \multicolumn{4}{|c|}{ Concentration } & \multirow{2}{*}{$\begin{array}{l}\text { Temper- } \\
\text { ature }\end{array}$} & \multirow{2}{*}{$\begin{array}{l}\text { Specific } \\
\text { gravity }\end{array}$} \\
\hline & & $\mathrm{NO}_{3}$ & $\mathrm{NO}_{2}$ & $\mathrm{AlO}_{2}$ & $\mathrm{OH}$ & & \\
\hline $\begin{array}{l}B X-7 R \\
B X-8 \\
B X-8 R \\
B X-8 P \\
B X-8 M \\
B X-8 N\end{array}$ & $\begin{array}{l}\mathrm{NO}_{2} \\
\mathrm{NO}_{2} \\
\mathrm{NO}_{2} \\
\mathrm{NO}_{2} \\
\mathrm{NO}_{2} \\
\mathrm{NO}_{2}\end{array}$ & $\begin{array}{l}3.14 \\
3.11 \\
3.17 \\
3.14 \\
2.06 \\
2.04\end{array}$ & $\begin{array}{l}6.38 \\
6.40 \\
6.51 \\
6.32 \\
6.40 \\
6.53\end{array}$ & $\begin{array}{l}1.12 \\
0.66 \\
0.68 \\
0.66 \\
0.71 \\
0.70\end{array}$ & $\begin{array}{l}4.95 \\
4.95 \\
5.04 \\
5.01 \\
5.33 \\
5.33\end{array}$ & $\begin{array}{l}80 \\
80 \\
80 \\
80 \\
80 \\
80\end{array}$ & $\begin{array}{l}1.632 \\
1.574 \\
1.604 \\
1.573 \\
1.552 \\
1.550\end{array}$ \\
\hline $\begin{array}{l}B X-9 A \\
B X-9 B \\
B X-9 C \\
B X-10 A \\
B X-10 B \\
B X-10 C \\
B X-11 A \\
B X-11 B \\
B X-12 A \\
B X-12 B \\
B X-12 C \\
B X-13 \\
B X-14 \\
B X-15 \\
B X-16\end{array}$ & $\begin{array}{l}A 10_{2} \\
A 10_{2} \\
A 10_{2} \\
A 10_{2} \\
A 10_{2} \\
A 10_{2} \\
A 10_{2} \\
A 10_{2} \\
A 10_{2} \\
A 10_{2} \\
A 10_{2} \\
A 10_{2} \\
A 10_{2} \\
A 10_{2} \\
A 10_{2}\end{array}$ & $\begin{array}{l}3.73 \\
3.54 \\
3.60 \\
3.88 \\
3.64 \\
3.80 \\
2.64 \\
2.48 \\
2.77 \\
2.57 \\
2.85 \\
3.84 \\
4.02 \\
2.75 \\
2.89\end{array}$ & $\begin{array}{l}4.68 \\
4.44 \\
4.52 \\
3.54 \\
3.33 \\
3.48 \\
4.85 \\
4.55 \\
3.70 \\
3.44 \\
3.82 \\
4.82 \\
3.67 \\
5.06 \\
3.87\end{array}$ & $\begin{array}{l}1.41 \\
1.23 \\
1.24 \\
1.49 \\
1.35 \\
1.40 \\
1.50 \\
1.30 \\
1.71 \\
1.39 \\
1.59 \\
1.37 \\
1.48 \\
1.59 \\
2.22\end{array}$ & $\begin{array}{l}4.13 \\
3.92 \\
3.99 \\
4.30 \\
4.03 \\
4.21 \\
4.28 \\
4.01 \\
4.49 \\
4.17 \\
4.53 \\
4.16 \\
4.35 \\
4.36 \\
4.59\end{array}$ & $\begin{array}{l}80 \\
80 \\
80 \\
80 \\
80 \\
80 \\
80 \\
80 \\
80 \\
80 \\
80 \\
80 \\
80 \\
80 \\
80\end{array}$ & $\begin{array}{l}1.61 \\
1.62 \\
1.60 \\
1.58 \\
1.58 \\
1.60 \\
1.56 \\
1.56 \\
1.54 \\
1.53 \\
1.55 \\
1.60 \\
1.58 \\
1.57 \\
1.55\end{array}$ \\
\hline $\begin{array}{l}B Y-1 \\
B Y-1 R \\
B Y-01 \\
B Y-2 \\
B Y-2 R \\
B Y-3 \\
B Y-03 \\
B Y-4\end{array}$ & $\begin{array}{l}\mathrm{NO}_{3} \\
\mathrm{NO}_{3} \\
\mathrm{NO}_{3} \\
\mathrm{NO} 3 \\
\mathrm{NO} 3 \\
\mathrm{NO}_{3} \\
\mathrm{NO} \\
\mathrm{NO} \\
\mathrm{NO}\end{array}$ & $\begin{array}{l}5.09 \\
5.09 \\
4.98 \\
5.26 \\
5.18 \\
5.21 \\
5.19 \\
5.56\end{array}$ & $\begin{array}{l}6.29 \\
6.27 \\
6.04 \\
6.48 \\
6.36 \\
4.48 \\
4.35 \\
4.68\end{array}$ & $\begin{array}{l}0.99 \\
0.99 \\
1.32 \\
0.60 \\
0.59 \\
1.04 \\
1.40 \\
0.64\end{array}$ & $\begin{array}{l}2.71 \\
2.75 \\
2.61 \\
2.76 \\
2.71 \\
2.85 \\
2.77 \\
2.93\end{array}$ & $\begin{array}{l}80 \\
80 \\
80 \\
80 \\
80 \\
80 \\
80 \\
80\end{array}$ & $\begin{array}{l}1.638 \\
1.635 \\
1.630 \\
1.624 \\
1.594 \\
1.562 \\
1.577 \\
1.573\end{array}$ \\
\hline $\begin{array}{l}B Y-5 \\
B Y-5 R \\
B Y-05 \\
B Y-6 \\
B Y-7 \\
B Y-7 R \\
B Y-07 \\
B Y-8\end{array}$ & $\begin{array}{l}\mathrm{NO}_{2} \\
\mathrm{NO}_{2} \\
\mathrm{NO}_{2} \\
\mathrm{NO}_{2} \\
\mathrm{NO}_{2} \\
\mathrm{NO} 2 \\
\mathrm{NO}_{2} \\
\mathrm{NO}_{2}\end{array}$ & $\begin{array}{l}4.72 \\
4.75 \\
4.56 \\
4.96 \\
3.06 \\
3.05 \\
2.98 \\
3.91\end{array}$ & $\begin{array}{l}6.63 \\
6.72 \\
6.58 \\
7.08 \\
7.06 \\
7.05 \\
7.03 \\
7.47\end{array}$ & $\begin{array}{l}0.97 \\
0.98 \\
1.30 \\
0.60 \\
1.06 \\
1.05 \\
1.42 \\
0.64\end{array}$ & $\begin{array}{l}2.66 \\
2.72 \\
2.58 \\
2.76 \\
2.93 \\
2.91 \\
2.81 \\
2.96\end{array}$ & $\begin{array}{l}80 \\
80 \\
80 \\
80 \\
80 \\
80 \\
80 \\
80\end{array}$ & $\begin{array}{l}1.615 \\
1.628 \\
1.620 \\
1.640 \\
1.565 \\
1.560 \\
1.587 \\
1.572\end{array}$ \\
\hline $\begin{array}{l}B Y-9 A \\
B Y-9 B \\
B Y-10 A \\
B Y-10 B \\
B Y-11 A\end{array}$ & $\begin{array}{l}A 10_{2} \\
A 10_{2} \\
A 10_{2} \\
A 10_{2} \\
A 10_{2}\end{array}$ & $\begin{array}{l}4.06 \\
3.94 \\
4.28 \\
4.16 \\
2.63\end{array}$ & $\begin{array}{l}5.34 \\
5.18 \\
3.81 \\
3.71 \\
5.77\end{array}$ & $\begin{array}{l}1.62 \\
1.54 \\
1.84 \\
1.72 \\
1.83\end{array}$ & $\begin{array}{l}2.28 \\
2.21 \\
2.40 \\
2.34 \\
2.47\end{array}$ & $\begin{array}{l}80 \\
80 \\
80 \\
80 \\
80\end{array}$ & $\begin{array}{l}1.62 \\
1.62 \\
1.58 \\
1.59 \\
1.60\end{array}$ \\
\hline
\end{tabular}


RHO-RE-ST-14 P

Sheet 5 of 7

\begin{tabular}{|c|c|c|c|c|c|c|c|}
\hline \multirow{2}{*}{$\begin{array}{l}\text { Run } \\
\text { No. }\end{array}$} & \multirow{2}{*}{ Variable } & \multicolumn{4}{|c|}{ Concentratiori } & \multirow{2}{*}{$\begin{array}{l}\text { Temper- } \\
\text { ature }\end{array}$} & \multirow{2}{*}{$\begin{array}{l}\text { Specific } \\
\text { gravity }\end{array}$} \\
\hline & & $\mathrm{NO}_{3}$ & $\mathrm{NO}_{2}$ & $A 10_{2}^{\prime}$ & $\mathrm{OH}$ & & \\
\hline $\begin{array}{l}B Y-11 B \\
B Y-12 B \\
B Y-12 C \\
B Y-12 D \\
B Y-13 \\
B Y-14 \\
B Y-15 \\
B Y-16\end{array}$ & $\begin{array}{l}\mathrm{A} 10_{2} \\
\mathrm{~A}_{2} \mathrm{O}_{2} \\
\mathrm{~A} 10_{2} \\
\mathrm{~A} 10_{2} \\
\mathrm{~A} 10_{2} \\
\mathrm{~A} 10_{2} \\
\mathrm{~A} 10_{2} \\
\mathrm{~A} 10_{2}\end{array}$ & $\begin{array}{l}2.51 \\
2.64 \\
2.67 \\
2.67 \\
3.96 \\
4.21 \\
2.54 \\
2.71\end{array}$ & $\begin{array}{l}5.50 \\
3.92 \\
3.97 \\
3.97 \\
5.20 \\
3.75 \\
5.57 \\
4.02\end{array}$ & $\begin{array}{l}1.71 \\
1.85 \\
2.05 \\
2.04 \\
1.59 \\
1.89 \\
1.91 \\
2.21\end{array}$ & $\begin{array}{l}2.35 \\
2.47 \\
2.50 \\
2.50 \\
2.22 \\
2.36 \\
2.38 \\
2.53\end{array}$ & $\begin{array}{l}80 \\
80 \\
80 \\
80 \\
80 \\
80 \\
80 \\
80\end{array}$ & $\begin{array}{l}1.58 \\
1.53 \\
1.55 \\
1.55 \\
1.61 \\
1.59 \\
1.58 \\
1.55\end{array}$ \\
\hline $\begin{array}{l}B Z-1 \\
B Z-1 R \\
B Z-2 \\
B Z-3 \\
B Z-4\end{array}$ & $\begin{array}{l}\mathrm{NO}_{3} \\
\mathrm{NO}_{3} \\
\mathrm{NO}_{3} \\
\mathrm{NO}_{3} \\
\mathrm{NO}_{3}\end{array}$ & $\begin{array}{l}4.29 \\
4.23 \\
4.28 \\
4.29 \\
4.34\end{array}$ & $\begin{array}{l}4.47 \\
4.42 \\
4.90 \\
2.94 \\
3.24\end{array}$ & $\begin{array}{l}1.04 \\
1.03 \\
0.62 \\
1.11 \\
0.66\end{array}$ & $\begin{array}{l}6.15 \\
6.08 \\
6.12 \\
6.56 \\
6.55\end{array}$ & $\begin{array}{l}80 \\
80 \\
80 \\
80 \\
80\end{array}$ & $\begin{array}{l}1.614 \\
1.595 \\
1.596 \\
1.572 \\
1.549\end{array}$ \\
\hline $\begin{array}{l}B Z-5 \\
B Z-5 R \\
B Z-6 \\
B Z-6 R \\
B Z-7 \\
B Z-8\end{array}$ & $\begin{array}{l}\mathrm{NO}_{2} \\
\mathrm{NO}_{2} \\
\mathrm{NO}_{2} \\
\mathrm{NO}_{2} \\
\mathrm{NO}_{2}^{-} \\
\mathrm{NO}_{2}\end{array}$ & $\begin{array}{l}3.54 \\
3.59 \\
3.95 \\
3.93 \\
2.35 \\
2.59\end{array}$ & $\begin{array}{l}5.48 \\
5.57 \\
5.64 \\
5.64 \\
5.61 \\
5.69\end{array}$ & $\begin{array}{l}1.02 \\
1.03 \\
0.62 \\
0.61 \\
1.09 \\
0.65\end{array}$ & $\begin{array}{l}6.00 \\
6.08 \\
6.08 \\
6.05 \\
6.43 \\
6.44\end{array}$ & $\begin{array}{l}80 \\
80 \\
80 \\
80 \\
80 \\
80\end{array}$ & $\begin{array}{l}1.598 \\
1.621 \\
1.613 \\
1.607 \\
1.572 \\
1.552\end{array}$ \\
\hline $\begin{array}{l}B Z-9 A \\
B Z-9 B \\
B Z-9 C \\
B Z-10 A \\
B Z-10 B \\
B Z-11 A \\
B Z-11 B \\
B Z-12 A \\
B Z-12 B\end{array}$ & $\begin{array}{l}A 10_{2} \\
A 10_{2} \\
A 10_{2} \\
A 10_{2} \\
A 10_{2} \\
A 10_{2} \\
A 10_{2} \\
A 10_{2} \\
A 10_{2}\end{array}$ & $\begin{array}{l}3.29 \\
3.15 \\
3.18 \\
3.49 \\
3.30 \\
2.14 \\
2.03 \\
2.27 \\
2.14\end{array}$ & $\begin{array}{l}4.04 \\
3.86 \\
3.91 \\
2.64 \\
2.50 \\
4.29 \\
4.06 \\
2.80 \\
2.63\end{array}$ & $\begin{array}{l}1.06 \\
1.03 \\
1.10 \\
1.23 \\
1.19 \\
1.23 \\
1.09 \\
1.30 \\
1.20\end{array}$ & $\begin{array}{l}5.30 \\
5.07 \\
5.12 \\
5.62 \\
5.32 \\
5.62 \\
5.32 \\
5.95 \\
5.61\end{array}$ & $\begin{array}{l}80 \\
80 \\
80 \\
80 \\
80 \\
80 \\
80 \\
80 \\
80\end{array}$ & $\begin{array}{l}1.57 \\
1.58 \\
1.57 \\
1.55 \\
1.55 \\
1.55 \\
1.55 \\
1.52 \\
1.52\end{array}$ \\
\hline $\begin{array}{l}C X-1 \\
C X-1 R \\
C X-2 \\
C X-3 \\
C X-4 \\
C X-4 R\end{array}$ & $\begin{array}{l}\mathrm{NO}_{3} \\
\mathrm{NO}_{3} \\
\mathrm{NO}_{3} \\
\mathrm{NO}_{3} \\
\mathrm{NO}_{3} \\
\mathrm{NO}_{3}\end{array}$ & $\begin{array}{l}5.83 \\
5.79 \\
5.84 \\
6.03 \\
6.19 \\
6.24\end{array}$ & $\begin{array}{l}5.83 \\
5.79 \\
5.84 \\
3.79 \\
3.88 \\
3.89\end{array}$ & $\begin{array}{l}0.90 \\
0.90 \\
0.55 \\
0.98 \\
0.61 \\
0.61\end{array}$ & $\begin{array}{l}4.14 \\
4.12 \\
4.16 \\
4.51 \\
4.63 \\
4.63\end{array}$ & $\begin{array}{l}100 \\
100 \\
100 \\
100 \\
100 \\
100\end{array}$ & $\begin{array}{l}1.662 \\
1.652 \\
1.624 \\
1.606 \\
1.601 \\
1.604\end{array}$ \\
\hline $\begin{array}{l}C X-5 \\
C X-5 R \\
C X-6 \\
C X-6 R \\
C X-7 \\
C X-8\end{array}$ & $\begin{array}{l}\mathrm{NO}_{2} \\
\mathrm{NO}_{2} \\
\mathrm{NO}_{2} \\
\mathrm{NO}_{2} \\
\mathrm{NO}_{2} \\
\mathrm{NO}_{2}\end{array}$ & $\begin{array}{l}4.75 \\
4.68 \\
4.78 \\
4.86 \\
2.73 \\
2.81\end{array}$ & $\begin{array}{l}7.55 \\
7.43 \\
7.60 \\
7.73 \\
7.83 \\
8.07\end{array}$ & $\begin{array}{l}0.88 \\
0.86 \\
0.53 \\
0.54 \\
0.96 \\
0.60\end{array}$ & $\begin{array}{l}4.03 \\
3.96 \\
4.05 \\
4.12 \\
4.41 \\
4.55\end{array}$ & $\begin{array}{l}100 \\
100 \\
100 \\
100 \\
100 \\
100\end{array}$ & $\begin{array}{l}1.666 \\
1.640 \\
1.635 \\
1.663 \\
1.588 \\
1.590\end{array}$ \\
\hline
\end{tabular}


RHO-RE-ST-14 P

Sheet 6 of 7

\begin{tabular}{|c|c|c|c|c|c|c|c|}
\hline \multirow{2}{*}{$\begin{array}{l}\text { Run } \\
\text { No. }\end{array}$} & \multirow{2}{*}{ Variable } & \multicolumn{4}{|c|}{ Concentration } & \multirow{2}{*}{$\begin{array}{c}\text { Temper- } \\
\text { ature }\end{array}$} & \multirow{2}{*}{$\begin{array}{l}\text { Specific } \\
\text { gravity }\end{array}$} \\
\hline & & $\mathrm{NO}_{3}$ & $\mathrm{NO}_{2}$ & $\mathrm{AlO}_{2}$ & $\mathrm{OH}$ & & \\
\hline $\begin{array}{l}C X-9 A \\
C X-9 B \\
C X-10 B \\
C X-10 C \\
C X-11 B \\
C X-11 C \\
C X-12 A \\
C X-12 B \\
C X-12 C\end{array}$ & $\begin{array}{l}A 10_{2} \\
A 10_{2} \\
A 10_{2} \\
A 10_{2} \\
A 10_{2} \\
A 10_{2} \\
A 10_{2} \\
A 10_{2} \\
A 10_{2}\end{array}$ & $\begin{array}{l}4.58 \\
4.44 \\
4.72 \\
4.69 \\
2.54 \\
2.51 \\
2.84 \\
2.74 \\
2.75\end{array}$ & $\begin{array}{l}5.45 \\
5.29 \\
3.36 \\
3.34 \\
5.70 \\
5.63 \\
3.81 \\
3.66 \\
3.69\end{array}$ & $\begin{array}{l}1.59 \\
1.61 \\
1.86 \\
1.59 \\
2.09 \\
1.66 \\
2.16 \\
2.02 \\
1.99\end{array}$ & $\begin{array}{l}3.86 \\
3.74 \\
3.98 \\
3.96 \\
4.04 \\
3.99 \\
4.51 \\
4.34 \\
4.37\end{array}$ & $\begin{array}{l}100 \\
100 \\
100 \\
100 \\
100 \\
100 \\
100 \\
100 \\
100\end{array}$ & $\begin{array}{l}1.66 \\
1.66 \\
1.61 \\
1.60 \\
1.60 \\
1.58 \\
1.55 \\
1.55 \\
1.56\end{array}$ \\
\hline $\begin{array}{l}C Y-1 \\
C Y-1 R \\
C Y-01 \\
C Y-2 \\
C Y-2 R \\
C Y-3 \\
C Y-03 \\
C Y-4\end{array}$ & $\begin{array}{l}\mathrm{NO}_{3} \\
\mathrm{NO}_{3} \\
\mathrm{NO}_{3} \\
\mathrm{NO}_{3} \\
\mathrm{NO}_{3} \\
\mathrm{NO}_{3} \\
\mathrm{NO}_{3} \\
\mathrm{NO}\end{array}$ & $\begin{array}{l}6.51 \\
6.34 \\
6.24 \\
6.56 \\
6.52 \\
6.79 \\
6.64 \\
6.99\end{array}$ & $\begin{array}{l}6.69 \\
6.52 \\
6.37 \\
6.76 \\
6.70 \\
4.14 \\
4.05 \\
4.25\end{array}$ & $\begin{array}{l}0.91 \\
0.89 \\
1.18 \\
0.53 \\
0.53 \\
0.98 \\
1.29 \\
0.58\end{array}$ & $\begin{array}{l}2.44 \\
2.38 \\
2.33 \\
2.45 \\
2.39 \\
2.62 \\
2.57 \\
2.62\end{array}$ & $\begin{array}{l}100 \\
100 \\
100 \\
100 \\
100 \\
100 \\
100 \\
100\end{array}$ & $\begin{array}{l}1.712 \\
1.667 \\
1.669 \\
1.680 \\
1.667 \\
1.609 \\
1.613 \\
1.602\end{array}$ \\
\hline $\begin{array}{l}C Y-5 \\
C Y-5 R \\
C Y-05 \\
C Y-6 \\
C Y-6 R \\
C Y-7 \\
C Y-07 \\
C Y-8 \\
C Y-8 R\end{array}$ & $\begin{array}{l}\mathrm{NO}_{2} \\
\mathrm{NO}_{2} \\
\mathrm{NO}_{2} \\
\mathrm{NO} 2 \\
\mathrm{NO} 2 \\
\mathrm{NO} 2 \\
\mathrm{NO}_{2} \\
\mathrm{NO}_{2} \\
\mathrm{~N}{ }_{2}\end{array}$ & $\begin{array}{l}5.35 \\
5.17 \\
5.05 \\
5.34 \\
5.35 \\
2.83 \\
2.79 \\
2.87 \\
2.84\end{array}$ & $\begin{array}{l}8.53 \\
8.22 \\
8.11 \\
8.54 \\
8.52 \\
9.01 \\
8.91 \\
9.20 \\
9.09\end{array}$ & $\begin{array}{l}0.90 \\
0.87 \\
1.15 \\
0.52 \\
0.52 \\
0.98 \\
1.32 \\
0.58 \\
0.58\end{array}$ & $\begin{array}{l}2.40 \\
2.32 \\
2.28 \\
2.34 \\
2.34 \\
2.64 \\
2.61 \\
2.62 \\
2.59\end{array}$ & $\begin{array}{l}100 \\
100 \\
100 \\
100 \\
100 \\
100 \\
100 \\
100 \\
100\end{array}$ & $\begin{array}{l}1.728 \\
1.668 \\
1.672 \\
1.681 \\
1.680 \\
1.615 \\
1.638 \\
1.593 \\
1.575\end{array}$ \\
\hline $\begin{array}{l}C Y-9 B \\
C Y-9 C \\
C Y-10 B \\
C Y-10 C \\
C Y-10 M \\
C Y-10 N \\
C Y-11 B \\
C Y-11 C \\
C Y-12 B \\
C Y-12 C\end{array}$ & $\begin{array}{l}A 10_{2} \\
A 10_{2} \\
A 10_{2} \\
A 10_{2} \\
A 10_{2} \\
A 10_{2} \\
A 10_{2} \\
A 10_{2} \\
A 10_{2} \\
A 10_{2}\end{array}$ & $\begin{array}{l}4.55 \\
4.50 \\
4.87 \\
4.96 \\
4.84 \\
4.73 \\
2.41 \\
2.40 \\
2.60 \\
2.61\end{array}$ & $\begin{array}{l}5.60 \\
5.53 \\
3.46 \\
3.52 \\
4.68 \\
4.57 \\
6.17 \\
6.14 \\
3.84 \\
3.87\end{array}$ & $\begin{array}{l}1.56 \\
1.74 \\
1.83 \\
2.29 \\
1.94 \\
1.95 \\
2.05 \\
2.01 \\
2.19 \\
2.22\end{array}$ & $\begin{array}{l}2.03 \\
2.01 \\
2.17 \\
2.21 \\
2.16 \\
2.11 \\
2.24 \\
2.23 \\
2.41 \\
2.42\end{array}$ & $\begin{array}{l}100 \\
100 \\
100 \\
100 \\
100 \\
100 \\
100 \\
100 \\
100 \\
100\end{array}$ & $\begin{array}{l}1.67 \\
1.65 \\
1.61 \\
1.64 \\
1.64 \\
1.65 \\
1.62 \\
1.61 \\
1.55 \\
1.56\end{array}$ \\
\hline $\begin{array}{l}C Z-1 \\
C Z-1 R \\
C Z-2 \\
C Z-2 R \\
C Z-3 \\
C Z-4\end{array}$ & $\begin{array}{l}\mathrm{NO}_{3} \\
\mathrm{NO}_{3} \\
\mathrm{NO} 3 \\
\mathrm{NO} 3 \\
\mathrm{NO} 3 \\
\mathrm{NO}_{3}\end{array}$ & $\begin{array}{l}5.56 \\
5.57 \\
5.64 \\
5.66 \\
5.70 \\
5.88\end{array}$ & $\begin{array}{l}5.72 \\
5.72 \\
5.88 \\
5.90 \\
3.74 \\
3.89\end{array}$ & $\begin{array}{l}0.86 \\
0.86 \\
0.54 \\
0.54 \\
0.94 \\
0.60\end{array}$ & $\begin{array}{l}5.06 \\
5.06 \\
5.19 \\
5.20 \\
5.55 \\
5.76\end{array}$ & $\begin{array}{l}100 \\
100 \\
100 \\
100 \\
100 \\
100\end{array}$ & $\begin{array}{l}1.650 \\
1.651 \\
1.649 \\
1.653 \\
1.601 \\
1.615\end{array}$ \\
\hline
\end{tabular}


RHO-RE-ST-14 P

Sheet 7 of 7

\begin{tabular}{|c|c|c|c|c|c|c|c|}
\hline \multirow{2}{*}{$\begin{array}{l}\text { Run } \\
\text { No. }\end{array}$} & \multirow{2}{*}{ Variable } & \multicolumn{4}{|c|}{ Concentration } & \multirow{2}{*}{$\begin{array}{l}\text { Temper- } \\
\text { ature }\end{array}$} & \multirow{2}{*}{$\begin{array}{l}\text { Specific } \\
\text { gravity }\end{array}$} \\
\hline & & $\mathrm{NO}_{3}$ & $\mathrm{NO}_{2}$ & $\mathrm{AlO}_{2}$ & $\mathrm{OH}$ & & \\
\hline $\begin{array}{l}C Z-5 \\
C Z-5 R \\
C Z-6 \\
C Z-6 R \\
C Z-7 \\
C Z-8\end{array}$ & $\begin{array}{l}\mathrm{NO}_{2} \\
\mathrm{NO}_{2} \\
\mathrm{NO}_{2} \\
\mathrm{NO}_{2} \\
\mathrm{NO}_{2} \\
\mathrm{NO}_{2}\end{array}$ & $\begin{array}{l}4.44 \\
4.27 \\
4.44 \\
4.36 \\
2.88 \\
2.95\end{array}$ & $\begin{array}{l}7.52 \\
7.24 \\
7.51 \\
7.36 \\
7.45 \\
7.63\end{array}$ & $\begin{array}{l}0.89 \\
0.86 \\
0.54 \\
0.53 \\
0.93 \\
0.58\end{array}$ & $\begin{array}{l}5.28 \\
5.08 \\
5.27 \\
5.16 \\
5.48 \\
5.61\end{array}$ & $\begin{array}{l}100 \\
100 \\
100 \\
100 \\
100 \\
100\end{array}$ & $\begin{array}{l}1.712 \\
1.649 \\
1.671 \\
1.638 \\
1.606 \\
1.603\end{array}$ \\
\hline $\begin{array}{l}C Z-9 A \\
C Z-9 B \\
C Z-9 C \\
C Z-10 A \\
C Z-10 B \\
C Z-11 A \\
C Z-11 B \\
C Z-12 A \\
C Z-12 B\end{array}$ & $\begin{array}{l}\mathrm{A} 10_{2} \\
A 10_{2} \\
A 10_{2} \\
A 10_{2} \\
A 10_{2} \\
A 10_{2} \\
A 10_{2} \\
A 10_{2} \\
A 10_{2}\end{array}$ & $\begin{array}{l}3.94 \\
3.85 \\
3.91 \\
4.26 \\
4.12 \\
2.63 \\
2.55 \\
2.83 \\
2.75\end{array}$ & $\begin{array}{l}5.30 \\
5.18 \\
5.26 \\
3.41 \\
3.30 \\
5.68 \\
5.50 \\
3.63 \\
3.53\end{array}$ & $\begin{array}{l}1.21 \\
1.22 \\
1.23 \\
1.50 \\
1.46 \\
1.60 \\
1.56 \\
1.46 \\
1.47\end{array}$ & $\begin{array}{l}4.73 \\
4.62 \\
4.69 \\
5.11 \\
4.94 \\
5.07 \\
4.90 \\
5.44 \\
5.29\end{array}$ & $\begin{array}{l}100 \\
100 \\
100 \\
100 \\
100 \\
100 \\
100 \\
100 \\
100\end{array}$ & $\begin{array}{l}1.63 \\
1.64 \\
1.64 \\
1.60 \\
1.60 \\
1.61 \\
1.61 \\
1.56 \\
1.57\end{array}$ \\
\hline
\end{tabular}


RHO-RE-ST-14 P

OISTRIBUTION

Number of Copies

OFFSITE

1

Savannah River Laboratory

Aiken, SC 29801

J. A. Reddick

ONSITE

Pacific Northwest Laboratory

A. M. Liebatrau

Westinghouse Hanford Company

E. D. Jension

Rockwe 11 Hanford Operations
M. R. Adams
M. G. Kelly
J. M. Allison
N. W. Kirch
R. B. Bendixsen
E. J. Kosiancic
D. E. Bowers
T. A. Lane
D. R. Brat:?e 1
J. H. L. Lawler
J. S. Buck ingham
D. W. Lindsey
K. G. Carothers
P. J. Certa
W. L. Louk
R. D. Claghorn
B. A. Meissner
R. M. Cleavenger
N. L. Pontious
C. H. Delegard
D. A. Reynolds
D. A. Dodd
G. T. Dukelow
W. R. Dwor:ak
H. R. Risenmay
L. H. Rodgers
L. M. Sasaki
M. I. Finernan
M. R. Fox
L. A. Gale
E. G. Gratny
R. E. Haal and
D. L. Hert ing
J. O. Honeyman
M. T. Jansky
L. Jensen
W. W. Schultz
J. P. Sloughter
G. B. Swancara
M. C. Teats
D. M. Tulberg
T. B. Veneziano
R. D. Wojtasek
Document Control (2)
Publication Services
Department (3) 